\title{
Fibrotic Events in the Progression of Cholestatic Liver Disease
}

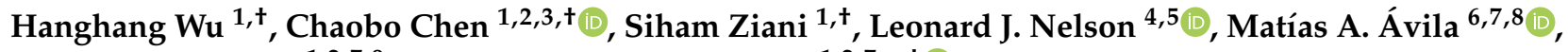 \\ Yulia A. Nevzorova ${ }^{1,2,7,9}$ and Francisco Javier Cubero $1,2,7, *,+\mathbb{D}$
}

1 Department of Immunology, Ophthalmology \& ENT, Complutense University School of Medicine, 28040 Madrid, Spain; travelerwhh@163.com (H.W.); bobo19820106@gmail.com (C.C.); sziani@ucm.es (S.Z.); yulianev@ucm.es (Y.A.N.)

2 Health Research Institute Gregorio Marañón (IiSGM), 28007 Madrid, Spain

3 Department of General Surgery, Wuxi Xishan People's Hospital, Wuxi 214000, China

4 Institute for Bioengineering (IBioE), School of Engineering, Faraday Building, The University of Edinburgh, Edinburgh EH9 3 JL, Scotland, UK; L.Nelson@ed.ac.uk

5 Institute of Biological Chemistry, Biophysics and Bioengineering (IB3), School of Engineering and Physical Sciences (EPS), Heriot-Watt University, Edinburgh EH14 4AS, Scotland, UK

6 Hepatology Program, Center for Applied Medical Research (CIMA), University of Navarra, 31008 Pamplona, Spain; maavila@unav.es

7 Centro de Investigacion Biomedica en Red, Enfermedades Hepáticas y Digestivas (CIBERehd), 28029 Madrid, Spain

8 Instituto de Investigaciones Sanitarias de Navarra IdiSNA, 31008 Pamplona, Spain

9 Department of Internal Medicine III, University Hospital RWTH Aachen, 52074 Aachen, Germany

* Correspondence: fcubero@ucm.es; Tel.: +34-91-394-1385; Fax: +34-91-394-1641

$\dagger$ These contributed equally as first authors.

Citation: Wu, H.; Chen, C.; Ziani, S.; Nelson, L.J.; Ávila, M.A.; Nevzorova, Y.A.; Cubero, F.J. Fibrotic Events in the Progression of Cholestatic Liver Disease. Cells 2021, 10, 1107. https://doi.org/10.3390/ cells10051107

Academic Editors: Ali Canbay and Ralf Weiskirchen

Received: 13 April 2021

Accepted: 30 April 2021

Published: 5 May 2021

Publisher's Note: MDPI stays neutral with regard to jurisdictional claims in published maps and institutional affiliations.

Copyright: (c) 2021 by the authors. Licensee MDPI, Basel, Switzerland. This article is an open access article distributed under the terms and conditions of the Creative Commons Attribution (CC BY) license (https:// creativecommons.org/licenses/by/ $4.0 /)$.

\begin{abstract}
Cholestatic liver diseases including primary biliary cholangitis (PBC) and primary sclerosing cholangitis (PSC) are associated with active hepatic fibrogenesis, which can ultimately lead to the development of cirrhosis. However, the exact relationship between the development of liver fibrosis and the progression of cholestatic liver disease remains elusive. Periductular fibroblasts located around the bile ducts seem biologically different from hepatic stellate cells (HSCs). The fibrotic events in these clinical conditions appear to be related to complex crosstalk between immune/inflammatory mechanisms, cytokine signalling, and perturbed homeostasis between cholangiocytes and mesenchymal cells. Several animal models including bile duct ligation (BDL) and the Mdr2-knockout mice have improved our understanding of mechanisms underlying chronic cholestasis. In the present review, we aim to elucidate the mechanisms of fibrosis in order to help to identify potential diagnostic and therapeutic targets.
\end{abstract}

Keywords: cholangiocytes; hepatic stellate cells (HSCs); periductular fibroblasts; cholestasis; fibrosis

\section{Introduction}

Cholestasis is a chronic liver disease characterised by bile flow obstruction in the liver, bile acid (BA) accumulation, and increased BA concentration in the systemic circulation. Thus, during cholestasis impaired bile formation and processing with insufficient bile reaching the duodenum, leads to the accumulation of intrahepatic and systemic BAs and other potentially toxic cholephilic bacteria. The aetiology of cholestasis includes disorders of bile secretion by hepatocytes and/or biliary epithelial cells (BECs), mechanical processes (e.g., stones, tumours) destroying/blocking smaller and/or larger intrahepatic bile ducts, or immune-mediated fibrotic cholangitis, such as primary biliary cholangitis (PBC) and primary sclerosing cholangitis (PSC) [1,2]. Therefore, BA metabolism plays an important role since the obstruction of bile flow leads to cholestatic injuries, such as in PBC and PSC [3].

Therapies for these diseases are, however, limited. Although ursodeoxycholic acid (UDCA) treatment can significantly improve the prognosis of PBC patients and pro- 
long transplant-free survival, the treatment options for those who do not respond to UDCA remain scarce. Other drugs associated with novel therapies in cholestatic diseases (PBC/PSC) are still in clinical trials, including obeticholic acid (OCA) [4], all-trans retinoic acid (ATRA) [5], Bezafibrate [6], Fenofibrate [7], etc. [8,9]. In addition, there are currently no available drugs to treat PSC [10]. Many of these disorders become chronic, therefore leading eventually to biliary cirrhosis and the need for liver transplantation [11]. Cholestatic liver disease can also cause liver failure and increase the risk of hepatocellular carcinoma (HCC) or cholangiocarcinoma (CCA) [12,13].

Several signalling pathways have been described in the development of cholestatic liver disease, such as NOTCH, IL- 6 and Wnt/ $\beta$-catenin pathways, transforming growth factor- $\beta$ (TGF- $\beta$ ) and hepatocyte nuclear factors (HNFs) $[14,15]$. There is increasing experimental evidence that immune cells strongly contribute to cholestatic liver disease, including $\mathrm{T}$ cells infiltrated in the liver in surgical (bile duct ligation, BDL) and genetic (multidrug resistance gene 2, Mdr2 $2^{-/}$knockout mice) preclinical models [16]. Patients diagnosed with $\mathrm{PBC}$, displayed infiltration of different subsets of immune cells in the portal tract areas [17]. In the present review, we discuss the mechanisms of fibrosis associated with the development of cholestatic liver disease, aiming to identify potential diagnostic and therapeutic targets.

\section{Primary Biliary Cholangitis (PBC)}

PBC, formerly known as primary biliary cirrhosis, is acquired chronic cholestasis related to the autoimmune destruction of small bile ducts, causing portal vein infiltration and fibrosis. $\mathrm{PBC}$ is a chronic progressive disease that leads to end-stage liver disease and its related complications [18-20]. It can progress to biliary cirrhosis, portal hypertension, liver failure, and is associated with esophagogastric variceal bleeding, ascites, and hepatic encephalopathy [21]. PBC is a destructive lymphocytic cholangitis and specific antimitochondrial antibodies (AMAs) target specific mitochondrial autoantigens [22]. It is characterised by the progressive damage and destruction of biliary epithelial cells (BECs; also called cholangiocytes) and increased portal vein inflammation and fibrosis [23,24], with chronic histological evidence, nonsuppurative, granulomatous, and lymphocytic cholangitis [21]. Simultaneously, in association with PBC, there are also symptoms that markedly affect the quality of life, including cholestatic pruritus, Sjogren's syndrome, abdominal discomfort, and fatigue $[25,26]$.

Approximately $95 \%$ of $\mathrm{PBC}$ patients are middle-aged women [27]. Interestingly, this disease rarely affects children [28]. The reports vary worldwide from 1970 to 2014, the annual incidence ranges from 0.3 to 5.8 per 100,000 , and the prevalence rates range from 1.9 to 40.2 per 100,000 individuals, respectively, due to increased incidence and improved survival [29-31]. From 2004 to 2014, in the United States, the prevalence of PBC increased significantly from 21.7 to 39.2 per 100,000, of which women rose from 33.5 to 57.8 per 100,000 (an increase of $72 \%$ ), while the incidence rate in men increased from 7.2 to 15.4 per 100,000 (an increase of 114\%) [32].

Risk factors for PBC include genetic factors such as the human leukocyte antigen (HLA) and non-HLA allelic variants) [33,34], as well as environmental stimuli. In addition to the regional differences in disease prevalence and family risk, the relationship between epidemiology and bacterial infection, xenobiotics, and smoking history also emphasises the importance of environmental triggers in the pathogenesis of PBC [35-41]. Furthermore, PBC development has also been linked to microRNA [42] and epigenetic regulation [22]. Moreover, the gut-liver axis is also involved in PBC development. Intestinal dysbacteriosis can affect the bile acid pool and regulate bile acid-activated receptors, which disturbs bile acid metabolism $[43,44]$. Simultaneously, several lines of evidence suggested that dysbiosis of gut microbiota can destroy the immune homeostasis, thus promoting PBC $[45,46]$.

Population-based historical data from the UK show that about $25 \%$ of untreated "classic PBC" patients develop chronic liver failure during this period [47]. An early prospective study found that more than $50 \%$ of patients with stage I-III PBC developed 
histologically confirmed cirrhosis within four years [48]. As cirrhotic individuals, PBC patients may develop complications due to the chronic nature of the disease. The presence of cirrhosis, regardless of its aetiology, is a major risk factor for hepatocellular carcinoma (HCC) or cholangiocarcinoma (CCA) [13,49].

\section{Primary Sclerosing Cholangitis (PSC)}

PSC is associated with liver damage, characterised by intrahepatic or extrahepatic bile duct injury, and fibrosis of the bile ducts inside and outside the liver, resulting in strictures of the bile ducts and obstruction of bile flow. Clinical manifestations reflect the potential sequence of bile duct injury and fibrosis leading to stricture, cholestasis, and biliary cirrhosis with progressive liver dysfunction [50]. PSC is a male-dominant disease when it is associated with inflammatory bowel disease (IBD), (65-70\%), with a male-female ratio of approximately 2:1 [27,51-53]. Epidemiological studies show that the prevalence of PSC is about 1/10,000 cases globally, while the incidence rate in northern Europe and the United States is $0.4 / 100,000$ to $2.0 / 100,000$ per year [54,55]. Simultaneously, the survival rate of PSC is increasing [51,56-58], which may be partly attributed to early diagnosis due to the application of magnetic resonance cholangiography (MRC). The clinical characteristics of newly diagnosed patients remain stable over time, while no new diagnostic methods were introduced during this period such as before fibrosis occurs [51].

PSC is a typical complex disease with genetic and environmental risk factors. This important genome-wide association has shown that PSC risk is associated with certain phenotypes of human leukocyte antigens (HLA), particularly HLA-DR6, HLA-DR3, and HLA-B8, suggesting the presence of autoimmune disorders in patients with PSC [59]. The risk of PSC is also associated with, at least, 23 regions of the genome [60]. At present, no clear causal environmental factor has been identified, however, the geographical distribution of the disease in northern Europe provides some clues to consider the source of environmental risk factors [61]. Indeed, differences in lifestyle, diet, and living conditions are highly regional [50]. Clinically, inflammatory bowel disease (IBD) is the strongest condition associated with PSC - approximately 70\% of patients with PSC having also IBD [62-64].

Bacterial cholangitis, osteoporosis, liver cirrhosis, and IBD can be caused by the progression of PSC [65-71]. It can lead to colorectal neoplasia, pancreatic cancer, CCA, and gallbladder carcinoma $[62,69,70,72-74]$. Large population-based studies indicate that the risk of death in patients with PSC is increased fourfold, in comparison with the general population [51]. The most common causes of death associated with PSC are CCA $(32 \%)$, liver failure (15\%), transplant-related complications (9\%), and colorectal cancer (8\%), demonstrating that the increased risk of malignancy for PSC has a significant impact on life expectancy [75].

\section{Key Hepatic Cells Involved in Disease Progression}

\subsection{Cholangiocytes and/or Biliary Epithelial Cells (BECs)}

Cholangiocytes are arranged in extrahepatic and intrahepatic bile ducts and modify the bile composition from hepatic cell tubules through the intrahepatic biliary tree. During gestation, from 12 to 16 weeks, the ductal plaque replicates in the discrete region, the expression of hepatocyte markers is inhibited, and markers of commitment towards the biliary phenotype including CK7 and CK19 begin to express [76]. Modification of bile occurs through coordinated transport of water, ions, and solutes across the apical and basolateral plasma membranes of cholangiocytes. This process is mediated by hormones, nucleotides, peptides, neurotransmitters, bile acids, and other molecules, through different signalling pathways [77].

Cholangiocytes are a group of target cells whose malfunction causes the so-called cholangiopathies, in which cholangiocytes react to exogenous and endogenous damage [78]. Cholangiocytes can be activated by a variety of injuries, including infection, cholestasis, ischemia, and xenobiotics [79]. Activated cholangiocytes are also involved in the recruitment and crosstalk of immune cells, vascular and mesenchymal cells, as well 
as the development of bile duct fibrosis and CCA under chronic stimuli. Features of activated BECs/cholangiocytes include increased proliferation, fibrogenesis, and proinflammatory secretions [14]. Depending on the of type insult, a series of morphogenetic signals and transcription factors are also involved and/or activated, including Notch, IL-6 and Wnt/ $\beta$-catenin pathways, TGF- $\beta$, and HNFs [15]. Recent studies have also shown that the SRY-box transcription factor 4 (SOX4) and SOX9 are involved in the development of primary cilia, and the normal formation, elongation, and branching of the bile duct trees [80]. These two factors cooperatively control the expression of mediators of TGF- $\beta$, Notch, and Hippo/Yes-associated protein 1 (YAP1) signalling pathways, which are required for normal biliary development. They are also related to the $\mathrm{Wnt} / \beta$-catenin signalling pathway and are involved in liver cilia disease [81], such as polycystic liver disease (PLD) [82].

\subsection{Periductular Fibroblasts and Hepatic Stellate Cells (HSCs)}

Fibrosis is an abnormal wound healing reaction arising from inflammation misregulation. In this process, chronic damage to any tissue will activate myofibroblasts and produce fibrous scars [3]. Myofibroblasts are rare in normal tissues, and their source depends on the tissue and type of injury. A plethora of evidence has shown that HSCs and portal fibroblasts (PFs) are the main sources of fibrotic liver myofibroblasts [83]. However, the composition of myofibroblasts varies depending on the pathogenesis of liver fibrosis. Hepatotoxic liver fibrosis (hepatic damage) is mainly caused by activation of HSCs [84], but activated PFs $(\mathrm{aPFs})$ are related to the pathogenesis of cholestatic fibrosis (obstruction of bile flow, such as in PBC and PSC [85]. PFs are 'periductular mesenchymal cells (or fibroblasts)' that maintain the integrity of the portal vein system [86]. As a response to biliary obstruction, portal (and/or myofibroblasts) proliferate, upregulate collagen I, $\alpha$-smooth muscle actin $(\alpha$ SMA), TGF- $\beta$, IL-6/13, and generate activated myofibroblasts $[87,88]$.

These activated myofibroblasts come from three main sources: hepatic stellate cells (HSCs), portal fibroblasts (PFs), and fibroblasts. Activated HSCs (aHSCs) are involved in the pathogenesis of experimental toxic liver fibrosis, such as $\mathrm{CCl}_{4}$-induced chronic liver disease and alcoholic liver disease [84]. PFs are mainly activated in the cholestatic liver fibrosis response in BDL or MDR2 knockout mice [85,89].

The embryological origin of PFs is unknown. PFs are located around the portal vein and maintain the integrity of the bile duct and portal vein system [90]. Under physiological conditions, they are composed of a small number of fibroblasts in the liver. In response to cholestatic injury, PFs proliferate, become activated, and mediate extracellular collagen I deposition [88,91]. It is also well known that during the development of the human liver, at the ductal plaque stage, the portal mesenchyme includes $\alpha$ SMA-positive cells. These $\alpha$ SMA-positive cells are not found during the ductal plate remodelling stage, and vimentin-expressing cells begin to appear, which are believed to be PFs. It seems that PFs are derived from $\alpha$ SMA-positive early mesenchymal cells [83,92] (Figure 1).

HSCs, or liver myofibroblasts, also named Ito cells, store vitamin A, and produce extracellular matrix (ECM) and collagen. HSCs play a role in the complex mechanisms of liver fibrosis and cirrhosis. They are also distributed between endothelial cells but are difficult to observe through an optical microscope [93,94]. Physiologically, quiescence HSCs (qHSCs) reside in the space of Disse (between hepatocytes and sinusoidal endothelial cells), store vitamin A and express specific markers such as glial fibrillary acidic protein (GFAP), synaptophysin, nerve growth factor p75 (NGFR, P75NTR) and lecithin retinol acyltransferase (Lrat) [3]. In response to injury, qHSCs differentiate into activated aHSCs, characterised by the expression of $\alpha \mathrm{SMA}$, become fibrogenic and mitogenic sensitive, and have the ability to actively secrete ECM proteins (especially laminin, collagen I, and III). This results in changes in the normal composition of the matrix, including cell-matrix interactions and the deposition of growth factors [95,96]. However, in response to toxic liver injury, HSCs downregulate the expression of vitamin A in lipid droplets, migrate to pericentral areas, then transdifferentiate into collagen I and $\alpha \mathrm{SMA}$ positive cells, indicative of myofibroblasts [89]. Activation of HSCs has been associated with cholesterol 
metabolism, as previously reported [97]. Extensive experimental results demonstrated that free cholesterol could be accumulated in HSCs, as an intracellular mediator promoting HSC activation, which may contribute to a vicious cycle of HSCs activation in liver fibrosis independently of serum cholesterol levels [98-100] (Figure 1).

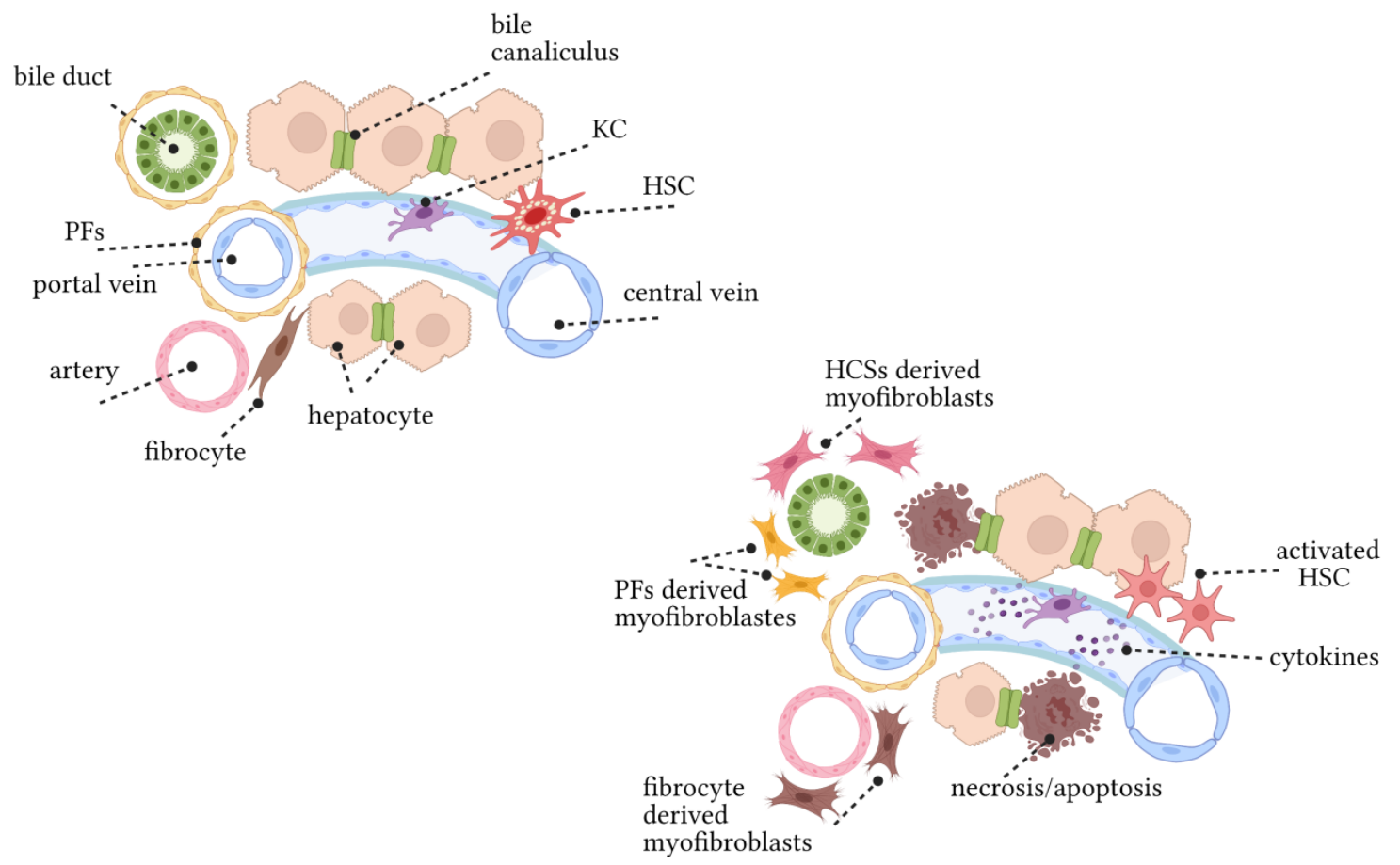

Figure 1. Pathogenesis of liver fibrosis. (Top left) The structure of liver lobules under physiological conditions. Biliary epithelial cells and hepatocytes, endothelial cells, HSCs, PFs, and KCs are the components of liver lobules. The bile duct, portal vein, and hepatic artery constitute the portal vein triad. HSCs are located in the space of Disse between hepatocytes and sinusoidal endothelium. HSCs are considered to be hepatic pericytes which contain lipid droplets and are the main storage cells for vitamin A. KCs are the resident liver macrophages. Only a few fibrocytes exist in a healthy liver. (Bottom right) Changes in liver lobules caused by chronic liver injury. In response to chronic liver injury, hepatocytes undergo apoptosis and release factors that recruit KCs, BM macrophages, and fibroblasts to sites of hepatic damage. KCs, macrophages, and fibroblasts release TGF $\beta 1$, which is one of the most powerful profibrogenic cytokines that can activate HSCs into collagen I-expressing myofibroblasts (e.g., $\alpha$ SMA). HSCs and PFs deposit ECM and a small number of fibroblasts.

Importantly, mesenchymal cells expressing the p75NTR in the mouse foetal liver have been shown to include precursors of PFs and HSCs. The p75NTR-positive cells are located in the periphery of the liver bud, later dividing into parenchymal and portal populations, which probably reveal HSCs and PFs [101]. The portal population of p75NTR-positive cells can regulate the commitment of hepatoblasts to a biliary lineage as they express the Notch ligand JAG1 [102]. The mesodermal origin of hematopoietic stem cells and perivascular mesenchymal cells (desmin ${ }^{+}, \mathrm{p} \mathrm{N} \mathrm{NTR}^{+}, \alpha \mathrm{SMA}^{+}$) has been demonstrated [103]. These perivascular mesenchymal cells may be the precursors of PFs, which suggests that HSCs and PFs come from a common precursor in the early embryo [83].

Specific markers for PFs include fibulin-2, IL-6, elastin, and ecto-ATPase nucleoside triphosphate diphosphohydrolase-2 (NTPD2). Useful markers to differentiate PFs from HSCs include the absence of lipid droplets and the expression of P100, $\alpha 2$-macroglobulin, and neuronal proteins such as the neuronal cell adhesion marker and synaptophysin [83]. The difference between aPFs and aHSCs is the expression of Thy1, Fibulin2, elastin, Gremlin1, extracellular ATPase, nucleoside triphosphate hydrolase 2, mesothelin (Msln), and mucin 16 (Muc16), as well as the lack of HSCs markers [89]. 


\section{Signalling Pathways Involved in Pathogenesis}

After cholangiocyte injury, infiltration of immune cells occurs, activating Notch, hedgehog $(\mathrm{Hh}), \mathrm{Wnt}$, and other signalling pathways_inducing the increase in fibroblasts due to HSCs activation, which further promote BECs proliferation. Subsequent pathological sequelae including biliary stricture formation, bile retention, bile-related toxic stress, inflammatory cells, or formation of immune cells around the bile duct further aggravate the disease.

\subsection{Notch Signalling Pathway}

In the past few years, the mechanisms and influence of Notch signalling in liver fibrosis have been developed. Rat HSCs express the Notch receptor in vitro and begin to express JAG1 after activation and differentiation into myofibroblast-like cells [104]. The expression of Notch 2/3, Hey $1 / 2$ increases significantly in the process leading from quiescent HSCs into activated myofibroblasts [105]. High activation of the Notch signal was also observed in hepatic progenitor cells isolated from tissues with PBC [106]. In addition, the number of Notch 1/3/4-positive cells increased significantly in the fibrotic area of Chemokine (C-C motif) ligands $4\left(\mathrm{CCl}_{4}\right)$-injured rats [107]. In the $\mathrm{CCl}_{4}$-induced rat liver fibrosis model, Notch signalling was also hyperactivated [108]. Moreover, inhibition of Notch in $\mathrm{CCl}_{4}$-induced liver injury significantly damaged HSC activation and triggered the development of fibrosis, and inhibition of this pathway in the liver can prevent or ameliorate fibrosis [109].

During liver fibrosis development, Notch interacts with other signalling pathways, such as TGF- $\beta$, Hippo, and Hh, whilst crosstalk between TGF- $\beta$ activation and Notch occurs in liver fibrosis $[110,111]$ (Figure 2 ). TGF- $\beta$ in the liver may partly promote fibrosis by stimulating Notch activity in HSCs. KCs together with bone marrow-derived macrophages are thought to be the main source of TGF- $\beta 1$ thus promoting the development of liver fibrosis $[112,113]$. Recent studies have shown that TGF- $\beta 2$-induced expression of fibrosis genes in cholangiocytes and HSCs is related to the specific regulation of the Notch3 signalling pathway [114]. SOX9, a transdifferentiated biomarker of BECs specifically expressed in cholangiocytes, is also a downstream target of Notch signalling. After BDL in rats, Notch receptor activation, combined with overexpression of SOX9, enhanced BEC proliferation and induced hyper-hepatic fibrosis [102]. Recently, another study from Athwal et al. [115] demonstrated the relationship between increased SOX9 and activation of the Hippo pathway in the development of liver fibrosis. Inhibition of YAP1 in $\mathrm{CCl}_{4}$ and BDL-induced liver fibrosis by injection of specific YAP1-related inhibitor Verteporfin resulted in decreased expression of SOX9 in HSCs. Notch and YAP1 may activate SOX9 in different cell types, both leading to HSCs activation and fibrosis induction [115-117]. Noticeably, YAP1/Hippo pathways are related to the activation and amplification of ductular reactive cells (DRC) [118,119]. Additionally, during tissue repair, which normally requires cell proliferation, the Hippo pathway is often downregulated by phosphorylation of its main effectors, yes-associated protein 1 (YAP1) and transcriptional co-activator with PDZ-binding motif (TAZ) [120]. In particular, macrophage-derived TNF-related weak inducer of apoptosis kinase (TWEAK) induced expansion of progenitor cells and proliferation of bile ducts in healthy mice, while fibroblast growth factor-inducible 14 (Fn14) deficient mice or neutralisation of TWEAK prevented the expansion of progenitor cells in cholestasis mice [121,122]. 


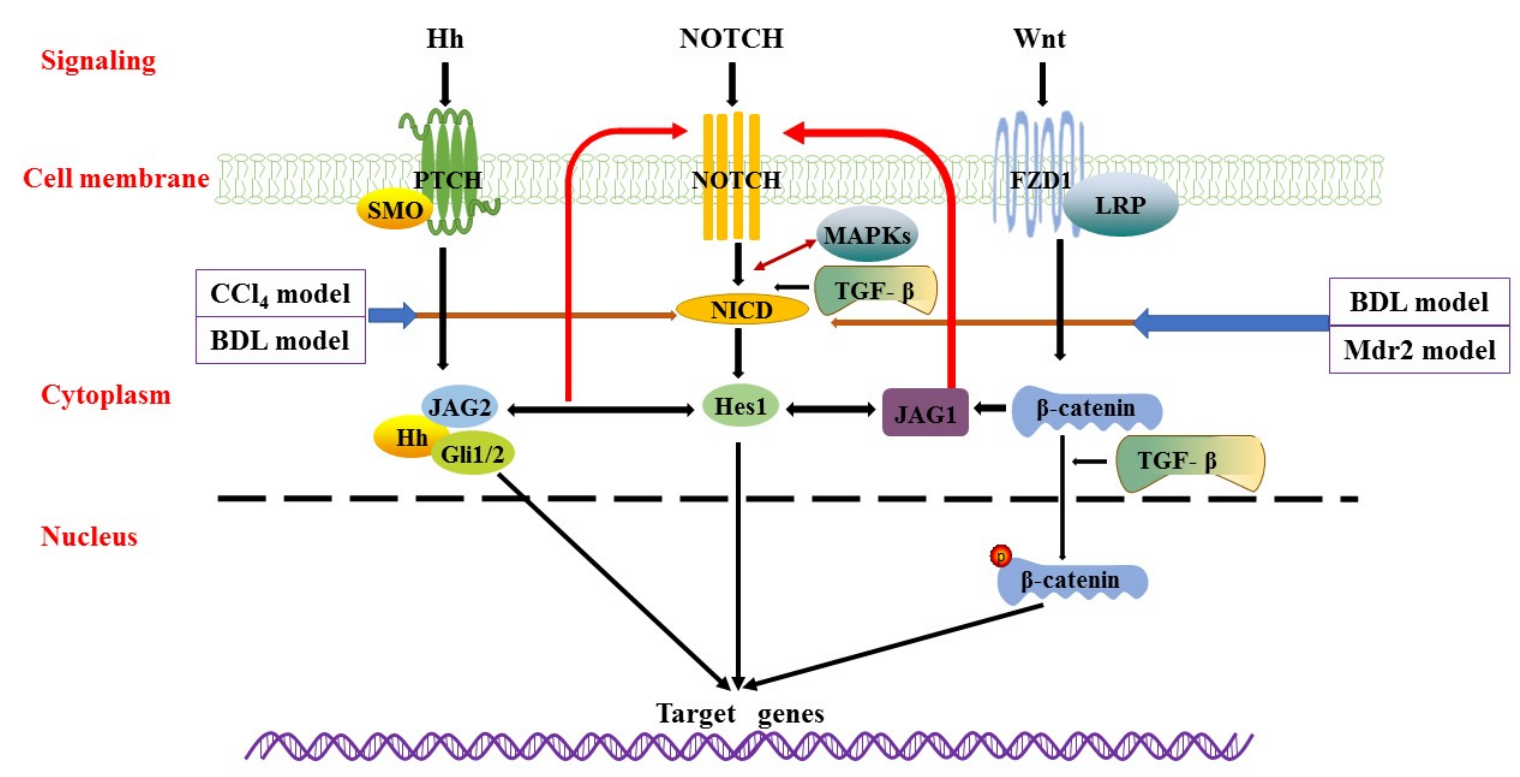

Figure 2. Wnt/ $\beta$-catenin, Notch, and Hedgehog signalling pathways. Wnt/ $\beta$-catenin signalling is transmitted through the Frizzled (FZD) receptor, thereby stabilizing $\beta$-catenin. Phosphorylated $\beta$-catenin translocated into the nucleus to regulate the expression of target genes. There is crosstalk between Wnt/ $\beta$-catenin signalling and Notch/TGF- $\beta$ signalling. In Notch signalling, binding of Notch ligands to the receptor results in two proteolytic cleavages to release NICD. The released NICD then translocated into the nucleus, activating transcription factors Hes1, JAG1, and JAG2, whilst the Notch signal pathway interacts with Hh and Wnt signalling pathways. In Hedgehog signalling, Hh ligand secreted by Hedgehog secretory cells binds to PTCH or SMO and generates activated Gli that translocated to the nucleus, inducing target gene expression. These main survival pathways and sophisticated interactions between signalling pathways (i.e., TGF- $\beta$ and MAPKs) constitute a complex regulatory network for the survival and proliferation of BECs.

\subsection{Hedgehog (Hh) Signalling Pathway}

$\mathrm{Hh}$ is one of the morphogenetic signalling pathways. There are three mammalian $\mathrm{Hh}$ proteins-Sonic hedgehog (Shh), Indian Hedgehog (Ihh), and Desert Hedgehog (Dhh). The downstream effector of Hh signalling is Gli1/2, a transcription repressor of the polycomb group and a central regulator of normal stem cell self-renewal. Regardless of the aetiology, it has been proved that the Hh signal is upregulated in the injured liver [123], and it increases with worsening of liver injury and fibrosis [124]. A previous study demonstrated liver accumulation of $\mathrm{Hh}$ ligands and activation of the Hh signalling pathway in the livers of BDL rodents and PBC patients [125]. Hh and Notch stimulate each other to promote HSCs activation and subsequent fibrosis [126]. In cholangiocytes, Notch promotes Shh signal transduction by regulating transport inside and outside primary cilium (PC), while Shh promotes Notch signal transduction by directly upregulating Hairy and enhancer of split-1 (Hes1) and Jagged canonical Notch ligand 2 (JAG2) [127] (Figure 2). In vitro and in vivo studies have shown that the Notch signalling pathway drives epithelial to mesenchymal transition (EMT). The interaction between Notch and $\mathrm{Hh}$ signalling pathways promotes the transdifferentiation of HSCs into myofibroblasts that involves an EMT, triggering fibrogenesis $[108,126]$. Finally, Notch also enhances the inflammatory response and M1 polarisation of macrophages [128].

\subsection{Wnt Signalling Pathway}

The Wnt signalling pathway is likely one of the main factors contributing to the progression of cholestatic liver disease. Wnt signal transduction induces liver fibrosis by promoting HSCs proliferation and activation, accompanied by ECM synthesis, EMT increase, or interaction with other fibrosis mediators [129,130]. Moreover, excessive accumulation of ECM is considered to be a key event in the pathogenesis of ageing-related liver fibrosis $[131,132]$. Several studies have shown that Wnt signalling is involved in the 
progression of liver fibrosis, and many components are upregulated and implicated in this process [133-136] (Figure 2). Conversely, the expression of some Wnt receptors (such as Frizzled 1 (FZD1)) and co-receptor low-density lipoprotein receptor-related protein 5/6 (LRP5/6) in activation of HSCs increased in the progression of liver fibrosis but with decreased expression of FZD4/8 [136-139]. Furthermore, $\beta$-catenin is the main downstream effector of classical Wnt signalling, and the loss function of $\beta$-catenin will affect the metabolism of BAs. In the BDL model, complete obstruction of bile flow can lead to hepatic cholestasis. Therefore, the enhanced inhibition of BAs synthesis by inhibiting or $\beta$-catenin loss can improve the progression of cholestasis. Interestingly, Pradhan [140] showed that the knockdown of $\beta$-catenin in $\mathrm{Mdr}^{-/-}$mice resulted in increased inflammation, cell senescence, promoted fibrosis, and impaired liver regeneration after injury. In Mdr2 ${ }^{-/-}$mice, this phenotype is mainly driven by the toxicity of BAs lacking phospholipids. Therefore, reducing injury, improving regenerative response, and/or maintaining bile flow to prevent stasis are essential for maintaining the liver function, at least in mice.

\subsection{Other Related Signalling Pathways}

In addition to the above signalling pathways, other studies have found that the c-Jun $\mathrm{N}$-terminal kinase (JNK), a member of the MAPKs family, is involved in the regulation of proliferation, cell death, inflammation, and metabolism [141,142]. JNK contributes to the activation of HSCs, induces overexpression of $\alpha \mathrm{SMA}$ during the procession of liver fibrosis [143,144], and promotes the production of myofibroblasts. Kluwe et al. [144] showed that the phosphorylation of JNK increased significantly in mouse liver after BDL or $\mathrm{CCl}_{4}$ administration, as well as in the human fibrotic liver, mainly in fibroblasts. In vivo, the inhibition using a pan-JNK inhibitor did not affect liver injury but significantly reduced fibrosis after BDL or $\mathrm{CCl}_{4}$. JNK1-deficient mice showed reduced fibrosis after BDL or $\mathrm{CCl}_{4}$, while JNK2-deficient mice showed increased fibrosis after BDL but no change after $\mathrm{CCl}_{4}$. In culture, pan-JNK inhibitors prevent the activation of human HSCs induced by TGF- $\beta$, PDGF, and angiotensin II-induced murine HSCs activation, and reduce PDGF and TGF- $\beta$ signal transduction. Zhao [143] showed the specific role of Jnk1 in HSC activation and ECM formation. The absence of Jnk1 correlated with a lower proliferation and survival of HSCs, demonstrating the pivotal contribution of Jnk1 in the development of liver fibrosis in HSCs. However, signalling pathways involved in JNK activation related to liver fibrosis are also participate in bidirectional crosstalk, including TNF- $\alpha$ and NF- $\mathrm{KB}$ [145]. Collectively, sustained activation of pre-fibrosis-related signalling pathways may promote the progression of liver fibrosis, combined with immune cell infiltration around biliary tracts.

\section{Pathophysiology}

\subsection{Hepatobiliary Acid-Base Balance Mitochondria miRNAs}

Although the complete pathogenesis of $\mathrm{PBC}$ remains elusive, the molecular mechanisms governing several stages during disease progression have been identified. The $\mathrm{Cl}^{-} / \mathrm{HCO}_{3}{ }^{-}$anion exchanger 2 (AE2) mediates $\mathrm{Cl}^{-} / \mathrm{HCO}_{3}{ }^{-}$exchange on the plasma membrane, regulates intracellular $\mathrm{pH}$, and bile $\mathrm{HCO}_{3}{ }^{-}$secretion, thus forming a bicarbonate rich 'umbrella' on the top surface of BECs, and protecting BECs from toxic hydrophobic BAs [146]. In cholestatic liver disease (such as PBC, PSC, cystic fibrosis-related liver disease (CFLD), and IgG4-related cholangitis (IRC), the dysregulation of the acid-base balance may be common [147]. It is noteworthy that the expression and activity of AE2 in liver and monocytes of PBC patients are decreased [148-150]. Therefore, it has been suggested that the reduction of the expression of AE2 leads to changes in BAs composition and may promote bile ductular injury [148-150]. In the AE2 knockout mouse model, IFN $\gamma$ and IL-12 production were enhanced, CD8+ T cells were expanded, T regulatory cells were downregulated, whilst antimitochondrial antibodies (AMAs) and mild histological evidence of severe portal inflammation were also found [151]. Recent evidence has revealed that the imbalance of miRNAs is associated with bile duct diseases [152], especially miR506. Erice et al. [153] found that the overexpression of miR506 was associated with abnormal 
expression of pyruvate dehydrogenase complex (PDC-E2). MiR506 is upregulated in the intrahepatic bile duct of $\mathrm{PBC}$ patients, regulating the secretion of BECs by negatively targeting AE2. In addition, miR506 also regulates type III inositol triphosphate receptor (InsP3R3), an intracellular $\mathrm{Ca}^{2+}$ channel in the endoplasmic reticulum that positively regulates bile duct secretion [153]. Proteomic analysis of human bile duct cells showed that upregulation of miR506 affected the metabolism of proteins involved in basic biological processes, especially in mitochondria [154]. In addition, in a mitochondrial stress test, overexpression of miR506 increased mitochondrial respiration rate, and ATP production was not proportional to oxygen consumption due to proton leakage in the mitochondrial inner membrane, resulting in decreased ATP production in cholangiocytes overexpressed with miR506 $[155,156]$. Upregulation of miRNA506 in cholangiocytes triggered a metabolic switch, which encompassed increased glycolysis, endoplasmic reticulum-associated oxidative stress, and DNA damage [157]. Overall, upregulation of miR506 in cholangiocytes induces a more stable PBC-like phenotype. In addition to miR506, there are other miRNAs implicated in cholestatic liver diseases such as miR33a, miR122a, and miR422a.

\subsection{Cholesterol Metabolism and Canalicular Transporters}

Cholesterol $7 \alpha$-hydroxylase (CYP7A1) and the canalicular bile salt export pump (BSEP) are two of several enzymes and transporters that play an important role in maintaining the bile acid reserve [158]. The microRNAs miR122a and miR422a have been reported to inhibit the translation of mRNA encoding CYP7A protein [159]. Overexpression of liver miR33, expressed from an intron of the sterol regulatory binding protein 2 (SREBP2) [160], reduces the bile acid reserve, increases liver cholesterol, and reduces cholesterol, in mouse serum. Furthermore, overexpression of CYP7A1 in mice has been shown to induce significant activation of SREBP2 regulated cholesterol metabolism. This suggests that the axis formed by CYP7A1-SREBP2-miR-33a plays an important role both in the regulation of hepatic cholesterol and in bile acid homeostasis [161,162]. Therefore, miRNAs represent an interesting target in the study of cholestatic liver diseases.

\subsection{Immune Targets}

AMAs mainly target the immunodominant PDC-E2 autoantigen which is located on the 2-oxo dehydrogenase complex (2-OADCs) in the inner membrane of mitochondria, while it only targets the small bile duct in PBC $[163,164]$. PDC-E2 auto reactive CD4 ${ }^{+}$ and $\mathrm{CD}^{+} \mathrm{T}$ cells are enriched in the liver and hilar lymph nodes of patients with early and advanced diseases $[165,166]$. Although AMAs may not be independently pathogenic in vivo, in the presence of macrophages and BECs apolipoproteins, pro-inflammatory cytokine bursts may develop, leading to chronic biliary tract inflammation [167]. In addition to hepatic immunoregulation, innate immunity, including natural killer (NK) cells and mucosal-associated invariant T cells (MAITs), and acquired immunity affect the development of PBC. Moreover, the HLA allele is one of the genetic factors critical to changing the way of antigen presentation to determine the sensitivity of $\mathrm{PBC}$, although the role of the HLA allele in the sensitivity of PBC is complex [168].

PSC is another type of autoimmune inflammatory liver disease. Although the influence of genetic and environmental factors is still unknown, our understanding of PSC genetics has made great progress in the last 10 years. As previously mentioned, a remarkable feature of PSC is that it is associated with IBD and ulcerative colitis (UC). GWAS showed that HLA loci in linkage disequilibrium $[169,170]$ exists between IBA and PSC. Typical fibrotic cholangitis with irregular narrowing of the bile duct tree and scar formation may be mediated by HLA-restricted T cell immunity in early stages, leading to the release of profibrogenic cytokines (such as TGF- $\beta$ ) and triggering an inflammatory cascade. The reaction involves other cell types in the matrix around the biliary tracts, such as fibroblasts. The interaction between damaged epithelial cells and subsequently activated stromal fibroblasts leads to a characteristic fibrotic response, resulting in biliary stricture and cholestasis, which further promotes parenchymal injury. The putative PSC sensitive 
gene encodes the key membrane surface bile salt receptor Takeda $G$ protein-coupled receptor 5 (TGR5) and the glycocalyx stabilizing enzyme fructosyltransferase 2 (FUT2), located in the cilia of apical cholangiocyte membranes acting as a chemosensor [171,172]. TGR5 and FUT2 can protect cholangiocytes against potentially toxic bile acids; therefore, their dysfunction may contribute to the development of chronic fibrotic cholangiopathy [173].

\section{Mouse Models of Cholestasis Liver Disease}

Previous studies with Mdr2 $2^{-/-}$mice models, a classic cholestasis model, showed that before the detectable histological and biochemical evidence of hepatic cell damage, significant hepatic neutrophil infiltration is observed after the elevation of pro-inflammatory cytokines [174]. Furthermore, compared with normal liver, there were more peribiliary M1- and M2-like monocyte-derived macrophages in the livers of Mdr2 ${ }^{-/-}$mice, an event also occurring in stage IV PSC patients [9]. Mdr2 has been found to be associated with cholestatic diseases. The P-glycoprotein encoded by Mdr2 plays an important role in the transport of phosphatidylcholine (PC) to the outer lobule of the tubular cell membrane, which helps to extract and excrete bile acids into bile [175]. In the Mdr2 ${ }^{-/-}$mouse model, mice fail to secrete PC into the bile, and bile becomes toxic due to the increased concentration of free nonmicellar BAs [176]. After the accumulation of toxic bile salts, the tight junctions and basement membranes of the bile duct are severely compromised. This leads to bile acid reflux into the portal vein, leading to nonsuppurative inflammatory cholangitis, periductal fibrosis, and ductal hyperplasia, of the 'onion-skin' type. In addition, atrophy and death of bile duct epithelial cells in 8-week-old mice led to the activation of fibroblasts around the duct, whilst fibrosis around the duct caused obstructive cholangitis [177].

BDL rodents are widely used experimental models to study obstructive cholestasis and proliferation of the bile ducts. In cases in which this surgical intervention induces acute obstructive jaundice with progression to cirrhosis with portal fibrosis, there is increased expression of pro-inflammatory cytokines such as TNF- $\alpha$ and IL- 6 and of profibrotic proteins such as collage- $\alpha 1$ [178]. The BDL program introduces biomechanical stress into bile duct epithelium and initially triggers compensatory proliferation and expansion of BECs $[179,180]$. Proliferative BECs can secrete a variety of profibrotic cytokines, promote the activation and proliferation of myofibroblasts and HSCs, and promote the synthesis of excessive ECM, thus initiating the development of chronic liver fibrosis [181].

A dominant-negative form of TGF- $\beta$ receptor type II (dnTGF $\beta$ RII) mice is also used as a model of cholestasis. TGF- $\beta$ is a cytokine that has pleiotropic roles on cell growth and differentiation. As a negative regulator of the immune system, it modulates the activation of regulatory $\mathrm{CD}^{+} \mathrm{T}$ cells [182]. In order to study the role of TGF $\beta 1$ in T cell homeostasis, dnTGF $\beta$ RII mice were generated under the control of the CD4 promoter, which resulted in the specific abolition of TGF $\beta 1$ signalling in CD4-positive T cells. In these mice, the absence of TGF $\beta 1$ causes the development of autoimmune inflammatory disease in several organs related to the production of different autoreactive antibodies [183,184]. Specifically, in the liver, dnTGF $\beta$ RII mice develop diverse characteristics of PBC with AMA-positive lymphoid cell infiltration of the portal spaces and elevated levels of serum cytokines such as IL-6, IFN $\gamma$, and TNF $\alpha$ [182]. Table 1 summarises autoantibodies in PBC and PSC. 
Table 1. Autoantibodies in PBC and PSC.

\begin{tabular}{ccc}
\hline Autoantibody & Target & Found Positive in Liver Disease \\
\hline AMAs & PDC-E2 & PBC [185,186] \\
& OGDC-E2 & \\
BCOADC-E2 & \\
E3BP & PBC and PSC [21,187,188] \\
gp210 & \\
p62 & sp100 & \\
PML & KLHL12 & PBC [189] \\
Anti-Kelch & ASGPR & PBC [190] \\
Anti-ASGPR & HK1 & PSC [191] \\
Anti-hexokinase & Unclear & PSC [193] \\
p-ANCA/p-ANNA & Gp2 & \\
Anti-GP2 IgA & S & \\
\hline AMAs, anti-mitochondrial antibodies; ANAs, antinuclear antibodies; OGDC-E2, 2-oxoglutarate dehydrogenase \\
complex; BCOADC, branched-chain 2-oxo-acid dehydrogenase complex; E3BP, E3-binding protein; gp210, \\
glycoprotein 210; sp100, nuclear body speckled 100 kDa; PML, promyelocytic leukaemia; KLHL12, Kelch-like 12; \\
ASGPR, asialoglycoprotein receptor; HK1, hexokinase 1; p-ANCA, perinuclear antineutrophil cytoplasmic \\
antibodies; p-ANNA, atypical p-ANCA; Gp2, Glycoprotein 2.
\end{tabular}

\section{Therapeutic Opportunities}

The treatment of cholestatic diseases includes surgical treatment and drug treatment. The key point of treatment for cholestasis in the early stages is based on reducing inflammation, as monitored by laboratory (i.e., transaminases or immunoglobulin $\mathrm{G}$ level) or histological evaluation in order to prevent or delay fibrosis. In drug therapy, UDCA is the first-line drug in clinic. UDCA has proven beneficial in about $60 \%$ of $\mathrm{PBC}$ patients but is less effective in PSC [194-196]. Obeticholic acid (OCA) is a synthetic derivative with anti-fibrotic effects [197]. Several OCA tests on PBC patients with insufficient UDCA reaction demonstrated that OCA can effectively improve the symptoms of patients. Currently, there is no drug therapy for PSC $[5,198]$. With the latest progress in molecular biochemistry especially related to bile acid regulation and the understanding of immune pathways, new drug therapies have emerged. Table 2 summarises new therapies in the treatment of PBS and PSC. In advanced stages of cholestasis, the main surgical treatment is liver transplantation, which is suitable for patients with advanced cirrhosis.

Table 2. Targets and drugs investigated for the treatment of PBS and PCS.

\begin{tabular}{|c|c|c|c|}
\hline \multirow{2}{*}{ Drug } & \multirow{2}{*}{ Mechanism of Action } & \multicolumn{2}{|c|}{ Reference and NCT Number } \\
\hline & & PBS & PCS \\
\hline \multicolumn{4}{|c|}{ Agonist (Target) } \\
\hline & & Levy et al. [199] & Ghonem et al. [200] \\
\hline Fenofibrate & PPAR $\alpha$ & NCT00575042 & NCT01142323 \\
\hline & & Corpechot et al. [201] & Elsemieke et al. [202] \\
\hline Bezatıbrate & Pan PPAR & NCT01654731 & NCT02701166 \\
\hline Fenofibrate and bezafibrate & $\operatorname{PPAR} \alpha$ & & Lemoinne et al. [203] \\
\hline Seladelpar & Selective PPAR $\delta$ & $\begin{array}{c}\text { Hirschfield et al. [204] } \\
\text { NCT02955602 }\end{array}$ & NCT04024813 \\
\hline Elafibranor & $\operatorname{PPAR} \alpha$ & $\begin{array}{c}\text { Schattenberg et al. [205] } \\
\text { NCT03124108 }\end{array}$ & \multirow{6}{*}{$\begin{array}{l}\text { Trauner et al. [207] } \\
\text { NCT02943460 }\end{array}$} \\
\hline Saroglitazar & & Lindor et al. [206] & \\
\hline saroglitazar & PPAR $\alpha$ and PPAK $\gamma$ & NCT03112681 & \\
\hline Cilofexor & FXR & NCT02943447 & \\
\hline Tropifexor & FXR & NCT02516605 & \\
\hline EDP-305 & FXR & $\begin{array}{c}\text { Goldstein et al. [208] } \\
\text { NCT03394924 }\end{array}$ & \\
\hline
\end{tabular}


Table 2. Cont.

\begin{tabular}{|c|c|c|c|}
\hline \multirow{2}{*}{ Drug } & \multirow{2}{*}{ Mechanism of Action } & \multicolumn{2}{|c|}{ Reference and NCT Number } \\
\hline & & PBS & PCS \\
\hline Etrasimod & $\begin{array}{l}\text { S1PR1 and S1PR4 } \\
\text { Inhibitor (Target) }\end{array}$ & NCT03155932 & \\
\hline GKT137831 & NOX1 and NOX4 & $\begin{array}{l}\text { Goldstein et al. [208] } \\
\text { NCT03226067 }\end{array}$ & \\
\hline Baricitinib & $\begin{array}{c}\text { JAK1 and JAK2 } \\
\text { Monoclonal antibody against } \\
\text { (Target) }\end{array}$ & NCT03742973 & \\
\hline Ustekinumab & IL-12 and IL-23 & $\begin{array}{l}\text { Hirschfield et al. [9] } \\
\quad \text { NCT01389973 }\end{array}$ & \\
\hline Abatacept & $\begin{array}{c}\text { CD80 and CD86 } \\
\text { interferes with T-cell activation }\end{array}$ & $\begin{array}{l}\text { Wagner et al. [209] } \\
\text { NCT02078882 }\end{array}$ & \\
\hline Rituximab & $\begin{array}{c}\text { CD20 } \\
\text { B-cell depletion }\end{array}$ & $\begin{array}{l}\text { Khanna et al. [210] } \\
\text { NCT02376335 }\end{array}$ & \\
\hline Infliximab & TNF- $\alpha$ & & Hommes et al. [8] \\
\hline Simtuzumab & LOXL2 & & $\begin{array}{l}\text { Muir et al. [211] } \\
\text { NCT01672853 }\end{array}$ \\
\hline E6011 & CX3CL1 (fractalkine) & $\begin{array}{l}\text { Goldstein et al. [208] } \\
\text { NCT03092765 }\end{array}$ & \\
\hline & $\begin{array}{l}\text { Antibiotics } \\
\text { Gut microbiome: antimicrobial } \\
\text { and immunomodulation }\end{array}$ & & \\
\hline Vancomycin & & $\begin{array}{l}\text { Ali et al. [212] } \\
\text { NCT01322386 }\end{array}$ & $\begin{array}{l}\text { Ali et al. [212] } \\
\text { NCT01802073 }\end{array}$ \\
\hline $\begin{array}{l}\text { Vancomycin and } \\
\text { metronidazole }\end{array}$ & & & $\begin{array}{l}\text { Tabibian et al. [213] } \\
\text { NCT01085760 }\end{array}$ \\
\hline Rifaximin & & & $\begin{array}{l}\text { Tabibian et al. [214] } \\
\text { NCT01695174 }\end{array}$ \\
\hline Probiotics & & NCT03521297 & \\
\hline ATRA & $\begin{array}{l}\text { Permissive activator of the } \\
\text { nuclear receptor FXR/RXR }\end{array}$ & & $\begin{array}{c}\text { Assis et al. [215] } \\
\text { NCT01456468 }\end{array}$ \\
\hline NGM282 & FGF 19 analogue & $\begin{array}{l}\text { Gochanour et al. [216] } \\
\text { NCT02026401 }\end{array}$ & $\begin{array}{l}\text { Hirschfield et al. [217] } \\
\text { NCT02704364 }\end{array}$ \\
\hline
\end{tabular}

PPAR- $\alpha$, peroxisome proliferator-activated receptor alpha; FXR, farnesoid X receptor; S1PR1, Sphingosine-1-phosphate receptor 1; S1PR4, Sphingosine-1-phosphate receptor 4; NOX1,NADPH oxidase 1; NOX4,NADPH oxidase 4; IL-12, interleukin 12; IL-23, interleukin 23; CD80, cluster of differentiation 80; CD86,cluster of differentiation 86; CD20,cluster of differentiation 20; TNF- $\alpha$, tumour necrosis factor alpha; LOXL2, lysyl oxidase-like 2; CX3CL1,C-X3-C motif chemokine ligand 1; ATRA, all-trans retinoic acid; FGF 19, fibroblast growth factor 19.

\section{Conclusions}

Cholestatic liver disease is characterised by impaired bile formation and transport, and insufficient bile reaching the duodenum, which, in turn, leads to the accumulation of BAs and other potentially toxic cholephilic bacteria inside and outside of the liver. PBC and PSC are common immune diseases that cause cholestatic cholangitis. Since the molecular mechanisms of cholestatic liver disease (such as PBC and PSC) are not fully understood, treatment options for cholestasis are limited. Even though short-term medication or use of normal drugs (e.g., OCA) can improve symptoms, they fail to halt disease progression. Although stimulation of bile secretion and adaptive mechanisms may reduce liver damage, in patients diagnosed with cholestatic liver disease, ultimately, liver transplantation is the only option to prolong life. Thus far, immune mechanisms targeting the pathogenesis of PBC and PSC have so far proved disappointing. In this review, we discussed the early initiation and developmental mechanisms of cholestatic liver disease combined with our current understanding of disease pathogenesis. Early activation of periductular fibroblasts, accompanied by inflammatory cytokines/factors around the bile duct, may be an important trigger for the inflammatory response that causes bile duct obstruction, involving HSCs and PFs, which are the main sources of fibrotic liver myofibroblasts. Furthermore, activation of periductular fibroblast-related signalling 
pathways, in turn, trigger the proliferation of myofibroblasts, collagen I deposition, and promotion of fibrogenesis, eventually leading to liver fibrosis and/or even irreversible liver cirrhosis. Therefore, if we can elucidate the pathological and molecular transduction pattern of cholestatic liver disease development and ascertain key events of the specific blockade that occurs, it could generate significant breakthroughs and allow progress in the diagnosis and treatment of cholestatic liver disease.

Author Contributions: Writing-original draft preparation, H.W. and C.C.; writing-review and editing, S.Z., L.J.N., M.A.Á., Y.A.N., and F.J.C.; original idea, F.J.C.; supervision and critical revision, F.J.C. All authors have read and agreed to the published version of the manuscript.

Funding: This research was funded by the MINECO Retos SAF2016-78711 and SAF2017-87919-R, MINECO PID2019-104878RB-100AEI/10.13039/501100011033, EXOHEP-CM S2017/BMD-3727, NanoLiver-CM Y2018/NMT-4949, ERAB Ref. EA 18/14, AMMF 2018/117, UCM-25-2019, the German Research Foundation (SFB/TRR57/P04, SFB 1382-403224013/A02 and DFG NE 2128/2-1), and COST Action CA17112. YAN and FJC are Ramón y Cajal Researcher RYC-2015-17438 and RYC-201415242 , respectively. FJC is a Gilead Liver Research 2018. The research group belongs to the validated Research Groups Ref. 970935 “Liver Pathophysiology”, 920631 “Lymphocyte immunobiology”, 920361 "Inmunogenética e inmunología de las mucosas" and IBL-6 (imas12-associated).

Conflicts of Interest: The funders had no role in the design of the study; in the collection, analyses, or interpretation of data; in the writing of the manuscript, or in the decision to publish the results.

$\begin{array}{ll}\text { Abbreviations } \\ \text { 2-OADCs } & \text { 2-oxo dehydrogenase complex } \\ \text { AE2 } & \text { anion exchanger 2 } \\ \text { AMAs } & \text { antimitochondrial antibodies } \\ \text { ATRA } & \text { all-trans retinoic acid } \\ \text { Bas } & \text { bile acids } \\ \text { BDL } & \text { bile duct ligation } \\ \text { BECs } & \text { biliary epithelial cells } \\ \text { CCA } & \text { Cholangiocarcinoma } \\ \text { CCl } & \text { C-C Motif Chemokine Ligand 4 } \\ \text { dnTGF } \beta \text { RII } & \text { dominant-negative form of TGF- } \beta \text { receptor type II } \\ \text { ECM } & \text { secrete extracellular matrix } \\ \text { EMT } & \text { epithelial-to-mesenchymal transition } \\ \text { FUT2 } & \text { glycocalyx stabilising enzyme fucosyltransferase 2 } \\ \text { UDCA } & \text { ursodeoxycholic acid } \\ \text { FZD1 } & \text { Frizzled 1 } \\ \text { GWAS } & \text { genome-wide association study } \\ \text { HCC } & \text { hepatocellular carcinoma } \\ \text { Hes1 } & \text { hairy and enhancer of split-1 } \\ \text { Hh } & \text { Hedgehog } \\ \text { HLA } & \text { human leukocyte antigen } \\ \text { HNFs } & \text { hepatocyte nuclear factors } \\ \text { HSCs } & \text { hepatic stellate cells } \\ \text { IBD } & \text { inflammatory bowel disease } \\ \text { IFNg } & \text { interferon gamma } \\ \text { IL-12 } & \text { interleukin 12 } \\ \text { IL-6 } & \text { interleukin 6 } \\ \text { JAG2 } & \text { jagged canonical notch ligand 2 } \\ \text { JNKs } & \text { c-Jun N-terminal kinases } \\ \text { LRP5/6 } & \text { low-density lipoprotein receptor-related protein5/6 } \\ & \end{array}$




$\begin{array}{ll}\text { MAIT } & \text { mucosal-associated invariant T cells } \\ \text { MRC } & \text { magnetic resonance cholangiography } \\ \text { NF- } \mathrm{B} \text { nuclear factor kappa-light-chain-enhancer of activated B cells } & \text { note diphosphohydrolase-2 } \\ \text { NTPD2 } & \text { ecto-ATPase nucleoside triphosphate dich } \\ \text { OCA } & \text { obeticholic acid } \\ \text { PBC } & \text { primary biliary cholangitis } \\ \text { PC } & \text { primary cilium } \\ \text { PDC-E2 } & \text { pyruvate dehydrogenase complex } \\ \text { PFs } & \text { portal fibroblasts } \\ \text { PLD } & \text { polycystic liver disease } \\ \text { PSC } & \text { primary sclerosing cholangitis } \\ \text { p75NTR } & \text { p75 neurotrophin receptor } \\ \text { SOX4 } & \text { SRY-box transcription factor } 4 \\ \text { SOX9 } & \text { SRY-box transcription factor } 9 \\ \text { TGF- } \beta & \text { transforming growth factor beta } \\ \text { TGR5 } & \text { Takeda G protein-coupled receptor } 5 \\ \text { TNF- } \alpha & \text { tumour necrosis factor- } \alpha \\ \text { UDCA } & \text { ursodeoxycholic acid } \\ \text { YAP1 } & \text { Yes-associated protein } 1 \\ \alpha \text { SMA } & \alpha \text {-smooth muscle actin }\end{array}$

\section{References}

1. Erlinger, S. What is cholestasis in 1985? J. Hepatol. 1985, 1, 687-693. [CrossRef]

2. Fuchs, C.D.; Halilbasic, E.; Trauner, M. Pathophysiologic basis for alternative therapies for cholestasis. Liver Biol. Pathobiol. 2020, 364-377. [CrossRef]

3. Bataller, R.; Brenner, D.A. Liver fibrosis. J. Clin. Investig. 2005, 115, 209-218. [CrossRef]

4. Kowdley, K.V.; Luketic, V.; Chapman, R.; Hirschfield, G.M.; Poupon, R.; Schramm, C.; Vincent, C.; Rust, C.; Pares, A.; Mason, A.; et al. A randomized trial of obeticholic acid monotherapy in patients with primary biliary cholangitis. Hepatology 2018, 67, 1890-1902. [CrossRef] [PubMed]

5. Nevens, F.; Andreone, P.; Mazzella, G.; Strasser, S.I.; Bowlus, C.; Invernizzi, P.; Drenth, J.P.; Pockros, P.J.; Regula, J.; Beuers, U.; et al. A placebo-controlled trial of obeticholic acid in primary biliary cholangitis. N. Engl. J. Med. 2016, 375, 631-643. [CrossRef]

6. Reig, A.; Sese, P.; Pares, A. Effects of bezafibrate on outcome and pruritus in primary biliary cholangitis with suboptimal ursodeoxycholic acid response. Am. J. Gastroenterol. 2018, 113, 49-55. [CrossRef] [PubMed]

7. Dejman, A.; Clark, V.; Martin, P.; Levy, C. Fenofibrate improves alkaline phosphatase in primary sclerosing cholangitis. Gastroenterology 2013, 144, S1028-S1029. [CrossRef]

8. Hommes, D.W.; Erkelens, W.; Ponsioen, C.; Stokkers, P.; Rauws, E.; van der Spek, M.; ten Kate, F.; van Deventer, S.J. A doubleblind, placebo-controlled, randomized study of infliximab in primary sclerosing cholangitis. J. Clin. Gastroenterol. 2008, 42, 522-526. [CrossRef] [PubMed]

9. Hirschfield, G.M.; Gershwin, M.E.; Strauss, R.; Mayo, M.J.; Levy, C.; Zou, B.; Johanns, J.; Nnane, I.P.; Dasgupta, B.; Li, K.; et al. Ustekinumab for patients with primary biliary cholangitis who have an inadequate response to ursodeoxycholic acid: $\mathrm{A}$ proof-of-concept study. Hepatology 2016, 64, 189-199. [CrossRef] [PubMed]

10. Santiago, P.; Scheinberg, A.R.; Levy, C. Cholestatic liver diseases: New targets, new therapies. Therap. Adv. Gastroenterol. 2018, 11, 1756284818787400. [CrossRef]

11. Cai, S.Y.; Li, M.; Boyer, J.L. The role of bile acid-mediated inflammation in cholestatic liver injury. Liver Biol. Pathobiol. 2020, 728-736. [CrossRef]

12. Bull, L.N.; Thompson, R.J. Progressive familial intrahepatic cholestasis. Clin. Liver Dis. 2018, 22, 657-669. [CrossRef] [PubMed]

13. Zollner, G.; Trauner, M. Mechanisms of cholestasis. Clin. Liver Dis. 2008, 12, 1-26. [CrossRef]

14. Mederacke, I.; Hsu, C.C.; Troeger, J.S.; Huebener, P.; Mu, X.; Dapito, D.H.; Pradere, J.P.; Schwabe, R.F. Fate tracing reveals hepatic stellate cells as dominant contributors to liver fibrosis independent of its aetiology. Nat. Commun. 2013, 4, 2823. [CrossRef]

15. Raynaud, P.; Carpentier, R.; Antoniou, A.; Lemaigre, F.P. Biliary differentiation and bile duct morphogenesis in development and disease. Int. J. Biochem Cell Biol. 2011, 43, 245-256. [CrossRef] [PubMed]

16. Yu, D.; Cai, S.Y.; Mennone, A.; Vig, P.; Boyer, J.L. Cenicriviroc, a cytokine receptor antagonist, potentiates all-trans retinoic acid in reducing liver injury in cholestatic rodents. Liver Int. 2018, 38, 1128-1138. [CrossRef] [PubMed]

17. Ma, W.T.; Chen, D.K. Immunological abnormalities in patients with primary biliary cholangitis. Clin. Sci. 2019, 133, 741-760. [CrossRef] [PubMed]

18. Carbone, M.; Mells, G.F.; Pells, G.; Dawwas, M.F.; Newton, J.L.; Heneghan, M.A.; Neuberger, J.M.; Day, D.B.; Ducker, S.J.; Consortium, U.P.; et al. Sex and age are determinants of the clinical phenotype of primary biliary cirrhosis and response to ursodeoxycholic acid. Gastroenterology 2013, 144, 560-569.e7. [CrossRef] 
19. Lammers, W.J.; van Buuren, H.R.; Hirschfield, G.M.; Janssen, H.L.; Invernizzi, P.; Mason, A.L.; Ponsioen, C.Y.; Floreani, A.; Corpechot, C.; Mayo, M.J.; et al. Levels of alkaline phosphatase and bilirubin are surrogate end points of outcomes of patients with primary biliary cirrhosis: An international follow-up study. Gastroenterology 2014, 147, 1338-1349.e5. [CrossRef]

20. Trivedi, P.J.; Lammers, W.J.; van Buuren, H.R.; Pares, A.; Floreani, A.; Janssen, H.L.; Invernizzi, P.; Battezzati, P.M.; Ponsioen, C.Y.; Corpechot, C.; et al. Stratification of hepatocellular carcinoma risk in primary biliary cirrhosis: A multicentre international study. Gut 2016, 65, 321-329. [CrossRef]

21. European Association for the Study of the Liver. Electronic address, e.e.e.; European Association for the Study of the, L. Easl clinical practice guidelines: The diagnosis and management of patients with primary biliary cholangitis. J. Hepatol. 2017, 67, 145-172. [CrossRef]

22. Gulamhusein, A.F.; Hirschfield, G.M. Primary biliary cholangitis: Pathogenesis and therapeutic opportunities. Nat. Rev. Gastroenterol. Hepatol. 2020, 17, 93-110. [CrossRef]

23. Beuers, U.; Gershwin, M.E.; Gish, R.G.; Invernizzi, P.; Jones, D.E.; Lindor, K.; Ma, X.; Mackay, I.R.; Pares, A.; Tanaka, A.; et al. Changing nomenclature for pbc: From 'cirrhosis' to 'cholangitis'. Gastroenterology 2015, 149, 1627-1629. [CrossRef] [PubMed]

24. Kaplan, M.M.; Gershwin, M.E. Primary biliary cirrhosis. N. Engl. J. Med. 2005, 353, 1261-1273. [CrossRef]

25. Dyson, J.K.; Wilkinson, N.; Jopson, L.; Mells, G.; Bathgate, A.; Heneghan, M.A.; Neuberger, J.; Hirschfield, G.M.; Ducker, S.J.; Consortium, U.-P.; et al. The inter-relationship of symptom severity and quality of life in 2055 patients with primary biliary cholangitis. Aliment. Pharmacol. Ther. 2016, 44, 1039-1050. [CrossRef]

26. Mells, G.F.; Pells, G.; Newton, J.L.; Bathgate, A.J.; Burroughs, A.K.; Heneghan, M.A.; Neuberger, J.M.; Day, D.B.; Ducker, S.J.; Sandford, R.N.; et al. Impact of primary biliary cirrhosis on perceived quality of life: The uk-pbc national study. Hepatology 2013, 58, 273-283. [CrossRef]

27. Li, T.; Chiang, J.Y. Bile acid metabolism in health and disease: An update. Liver Biol. Pathobiol. 2020, 269-285. [CrossRef]

28. Gonzalez, R.S.; Washington, K. Primary biliary cholangitis and autoimmune hepatitis. Surg. Pathol. Clin. 2018, 11, 329-349. [CrossRef] [PubMed]

29. Boonstra, K.; Kunst, A.E.; Stadhouders, P.H.; Tuynman, H.A.; Poen, A.C.; van Nieuwkerk, K.M.; Witteman, E.M.; Hamann, D.; Witteman, B.J.; Beuers, U.; et al. Rising incidence and prevalence of primary biliary cirrhosis: A large population-based study. Liver Int. 2014, 34, e31-e38. [CrossRef]

30. Dahlqvist, G.; Gaouar, F.; Carrat, F.; Meurisse, S.; Chazouilleres, O.; Poupon, R.; Johanet, C.; Corpechot, C.; French network of Immunology, L. Large-scale characterization study of patients with antimitochondrial antibodies but nonestablished primary biliary cholangitis. Hepatology 2017, 65, 152-163. [CrossRef] [PubMed]

31. Griffiths, L.; Dyson, J.K.; Jones, D.E. The new epidemiology of primary biliary cirrhosis. Semin. Liver Dis. 2014, 34, 318-328. [CrossRef]

32. Lu, M.; Zhou, Y.; Haller, I.V.; Romanelli, R.J.; VanWormer, J.J.; Rodriguez, C.V.; Anderson, H.; Boscarino, J.A.; Schmidt, M.A.; Daida, Y.G.; et al. Increasing prevalence of primary biliary cholangitis and reduced mortality with treatment. Clin. Gastroenterol. Hepatol. 2018, 16, 1342-1350.e1. [CrossRef]

33. Gulamhusein, A.F.; Juran, B.D.; Lazaridis, K.N. Genome-wide association studies in primary biliary cirrhosis. Semin. Liver Dis. 2015, 35, 392-401. [CrossRef]

34. Trivedi, P.J.; Hirschfield, G.M. The immunogenetics of autoimmune cholestasis. Clin. Liver Dis. 2016, 20, 15-31. [CrossRef]

35. Corpechot, C.; Chretien, Y.; Chazouilleres, O.; Poupon, R. Demographic, lifestyle, medical and familial factors associated with primary biliary cirrhosis. J. Hepatol. 2010, 53, 162-169. [CrossRef]

36. Gershwin, M.E.; Selmi, C.; Worman, H.J.; Gold, E.B.; Watnik, M.; Utts, J.; Lindor, K.D.; Kaplan, M.M.; Vierling, J.M.; Group, U.P.E. Risk factors and comorbidities in primary biliary cirrhosis: A controlled interview-based study of 1032 patients. Hepatology 2005, 42, 1194-1202. [CrossRef]

37. Hamlyn, A.N.; Macklon, A.F.; James, O. Primary biliary cirrhosis: Geographical clustering and symptomatic onset seasonality. Gut 1983, 24, 940-945. [CrossRef] [PubMed]

38. Invernizzi, P. Human leukocyte antigen in primary biliary cirrhosis: An old story now reviving. Hepatology 2011, 54, 714-723. [CrossRef] [PubMed]

39. Juran, B.D.; Lazaridis, K.N. Environmental factors in primary biliary cirrhosis. Semin. Liver Dis. 2014, 34, 265-272. [CrossRef] [PubMed]

40. Probert, P.M.; Leitch, A.C.; Dunn, M.P.; Meyer, S.K.; Palmer, J.M.; Abdelghany, T.M.; Lakey, A.F.; Cooke, M.P.; Talbot, H.; Wills, C.; et al. Identification of a xenobiotic as a potential environmental trigger in primary biliary cholangitis. J. Hepatol. 2018, 69, 1123-1135. [CrossRef]

41. Wang, J.J.; Yang, G.X.; Zhang, W.C.; Lu, L.; Tsuneyama, K.; Kronenberg, M.; Vela, J.L.; Lopez-Hoyos, M.; He, X.S.; Ridgway, W.M.; et al. Escherichia coli infection induces autoimmune cholangitis and anti-mitochondrial antibodies in non-obese diabetic (nod).B6 (idd10/idd18) mice. Clin. Exp. Immunol. 2014, 175, 192-201. [CrossRef] [PubMed]

42. Seidel, D.; Eickmeier, I.; Kuhl, A.A.; Hamann, A.; Loddenkemper, C.; Schott, E. Cd8 t cells primed in the gut-associated lymphoid tissue induce immune-mediated cholangitis in mice. Hepatology 2014, 59, 601-611. [CrossRef]

43. Li, Y.; Tang, R.; Leung, P.S.C.; Gershwin, M.E.; Ma, X. Bile acids and intestinal microbiota in autoimmune cholestatic liver diseases. Autoimmun. Rev. 2017, 16, 885-896. [CrossRef] 
44. Chen, W.; Wei, Y.; Xiong, A.; Li, Y.; Guan, H.; Wang, Q.; Miao, Q.; Bian, Z.; Xiao, X.; Lian, M.; et al. Comprehensive analysis of serum and fecal bile acid profiles and interaction with gut microbiota in primary biliary cholangitis. Clin. Rev. Allergy Immunol. 2020, 58, 25-38. [CrossRef] [PubMed]

45. Grant, A.J.; Lalor, P.F.; Salmi, M.; Jalkanen, S.; Adams, D.H. Homing of mucosal lymphocytes to the liver in the pathogenesis of hepatic complications of inflammatory bowel disease. Lancet 2002, 359, 150-157. [CrossRef]

46. Jimenez-Dalmaroni, M.J.; Gerswhin, M.E.; Adamopoulos, I.E. The critical role of toll-like receptors-from microbial recognition to autoimmunity: A comprehensive review. Autoimmun. Rev. 2016, 15, 1-8. [CrossRef] [PubMed]

47. Prince, M.; Chetwynd, A.; Newman, W.; Metcalf, J.V.; James, O.F. Survival and symptom progression in a geographically based cohort of patients with primary biliary cirrhosis: Follow-up for up to 28 years. Gastroenterology 2002, 123, 1044-1051. [CrossRef]

48. Christensen, E.; Neuberger, J.; Crowe, J.; Altman, D.G.; Popper, H.; Portmann, B.; Doniach, D.; Ranek, L.; Tygstrup, N.; Williams, R. Beneficial effect of azathioprine and prediction of prognosis in primary biliary cirrhosis. Final results of an international trial. Gastroenterology 1985, 89, 1084-1091. [CrossRef]

49. Jones, D.E.; Metcalf, J.V.; Collier, J.D.; Bassendine, M.F.; James, O.F. Hepatocellular carcinoma in primary biliary cirrhosis and its impact on outcomes. Hepatology 1997, 26, 1138-1142. [CrossRef] [PubMed]

50. Dyson, J.K.; Beuers, U.; Jones, D.E.J.; Lohse, A.W.; Hudson, M. Primary sclerosing cholangitis. Lancet 2018, 391, 2547-2559. [CrossRef]

51. Boonstra, K.; Weersma, R.K.; van Erpecum, K.J.; Rauws, E.A.; Spanier, B.W.; Poen, A.C.; van Nieuwkerk, K.M.; Drenth, J.P.; Witteman, B.J.; Tuynman, H.A.; et al. Population-based epidemiology, malignancy risk, and outcome of primary sclerosing cholangitis. Hepatology 2013, 58, 2045-2055. [CrossRef] [PubMed]

52. Schrumpf, E.; Abdelnoor, M.; Fausa, O.; Elgjo, K.; Jenssen, E.; Kolmannskog, F. Risk factors in primary sclerosing cholangitis. J. Hepatol. 1994, 21, 1061-1066. [CrossRef]

53. Tischendorf, J.J.; Hecker, H.; Kruger, M.; Manns, M.P.; Meier, P.N. Characterization, outcome, and prognosis in 273 patients with primary sclerosing cholangitis: A single center study. Am. J. Gastroenterol. 2007, 102, 107-114. [CrossRef]

54. Jepsen, P.; Gronbaek, L.; Vilstrup, H. Worldwide incidence of autoimmune liver disease. Dig. Dis. 2015, 33 (Suppl. 2), 2-12. [CrossRef]

55. Molodecky, N.A.; Kareemi, H.; Parab, R.; Barkema, H.W.; Quan, H.; Myers, R.P.; Kaplan, G.G. Incidence of primary sclerosing cholangitis: A systematic review and meta-analysis. Hepatology 2011, 53, 1590-1599. [CrossRef]

56. Bambha, K.; Kim, W.R.; Talwalkar, J.; Torgerson, H.; Benson, J.T.; Therneau, T.M.; Loftus, E.V., Jr.; Yawn, B.P.; Dickson, E.R.; Melton, L.J., 3rd. Incidence, clinical spectrum, and outcomes of primary sclerosing cholangitis in a united states community. Gastroenterology 2003, 125, 1364-1369. [CrossRef] [PubMed]

57. Escorsell, A.; Pares, A.; Rodes, J.; Solis-Herruzo, J.A.; Miras, M.; de la Morena, E. Epidemiology of primary sclerosing cholangitis in spain. Spanish association for the study of the liver. J. Hepatol. 1994, 21, 787-791. [CrossRef]

58. Lindkvist, B.; Benito de Valle, M.; Gullberg, B.; Bjornsson, E. Incidence and prevalence of primary sclerosing cholangitis in a defined adult population in sweden. Hepatology 2010, 52, 571-577. [CrossRef] [PubMed]

59. Liu, J.Z.; Hov, J.R.; Folseraas, T.; Ellinghaus, E.; Rushbrook, S.M.; Doncheva, N.T.; Andreassen, O.A.; Weersma, R.K.; Weismuller, T.J.; Eksteen, B.; et al. Dense genotyping of immune-related disease regions identifies nine new risk loci for primary sclerosing cholangitis. Nat. Genet. 2013, 45, 670-675. [CrossRef]

60. Ji, S.G.; Juran, B.D.; Mucha, S.; Folseraas, T.; Jostins, L.; Melum, E.; Kumasaka, N.; Atkinson, E.J.; Schlicht, E.M.; Liu, J.Z.; et al. Genome-wide association study of primary sclerosing cholangitis identifies new risk loci and quantifies the genetic relationship with inflammatory bowel disease. Nat. Genet. 2017, 49, 269-273. [CrossRef]

61. de Vries, A.B.; Janse, M.; Blokzijl, H.; Weersma, R.K. Distinctive inflammatory bowel disease phenotype in primary sclerosing cholangitis. World J. Gastroenterol. 2015, 21, 1956-1971. [CrossRef]

62. Katt, J.; Schwinge, D.; Schoknecht, T.; Quaas, A.; Sobottka, I.; Burandt, E.; Becker, C.; Neurath, M.F.; Lohse, A.W.; Herkel, J.; et al. Increased thelper type 17 response to pathogen stimulation in patients with primary sclerosing cholangitis. Hepatology 2013, 58, 1084-1093. [CrossRef]

63. Sabino, J.; Vieira-Silva, S.; Machiels, K.; Joossens, M.; Falony, G.; Ballet, V.; Ferrante, M.; Van Assche, G.; Van der Merwe, S.; Vermeire, S.; et al. Primary sclerosing cholangitis is characterised by intestinal dysbiosis independent from ibd. Gut 2016, 65, 1681-1689. [CrossRef] [PubMed]

64. Wiesner, R.H.; Grambsch, P.M.; Dickson, E.R.; Ludwig, J.; MacCarty, R.L.; Hunter, E.B.; Fleming, T.R.; Fisher, L.D.; Beaver, S.J.; LaRusso, N.F. Primary sclerosing cholangitis: Natural history, prognostic factors and survival analysis. Hepatology 1989, 10, 430-436. [CrossRef] [PubMed]

65. Bader, T.R.; Beavers, K.L.; Semelka, R.C. Mr imaging features of primary sclerosing cholangitis: Patterns of cirrhosis in relationship to clinical severity of disease. Radiology 2003, 226, 675-685. [CrossRef] [PubMed]

66. Bjornsson, E.; Lindqvist-Ottosson, J.; Asztely, M.; Olsson, R. Dominant strictures in patients with primary sclerosing cholangitis. Am. J. Gastroenterol. 2004, 99, 502-508. [CrossRef] [PubMed]

67. Broome, U.; Lofberg, R.; Veress, B.; Eriksson, L.S. Primary sclerosing cholangitis and ulcerative colitis: Evidence for increased neoplastic potential. Hepatology 1995, 22, 1404-1408.

68. Chapman, R.; Fevery, J.; Kalloo, A.; Nagorney, D.M.; Boberg, K.M.; Shneider, B.; Gores, G.J.; American Association for the Study of Liver, D. Diagnosis and management of primary sclerosing cholangitis. Hepatology 2010, 51, 660-678. [CrossRef] [PubMed] 
69. Claessen, M.M.; Vleggaar, F.P.; Tytgat, K.M.; Siersema, P.D.; van Buuren, H.R. High lifetime risk of cancer in primary sclerosing cholangitis. J. Hepatol. 2009, 50, 158-164. [CrossRef]

70. European Association for the Study of the, L. Easl clinical practice guidelines: Management of cholestatic liver diseases. J. Hepatol. 2009, 51, 237-267. [CrossRef]

71. Linder, S.; Soderlund, C. Endoscopic therapy in primary sclerosing cholangitis: Outcome of treatment and risk of cancer. Hepatogastroenterology 2001, 48, 387-392. [PubMed]

72. Bergquist, A.; Ekbom, A.; Olsson, R.; Kornfeldt, D.; Loof, L.; Danielsson, A.; Hultcrantz, R.; Lindgren, S.; Prytz, H.; Sandberg-Gertzen, H.; et al. Hepatic and extrahepatic malignancies in primary sclerosing cholangitis. J. Hepatol. 2002, 36, 321-327. [CrossRef]

73. Boberg, K.M.; Bergquist, A.; Mitchell, S.; Pares, A.; Rosina, F.; Broome, U.; Chapman, R.; Fausa, O.; Egeland, T.; Rocca, G.; et al. Cholangiocarcinoma in primary sclerosing cholangitis: Risk factors and clinical presentation. Scand. J. Gastroenterol. 2002, 37, 1205-1211. [CrossRef] [PubMed]

74. Fevery, J.; Henckaerts, L.; Van Oirbeek, R.; Vermeire, S.; Rutgeerts, P.; Nevens, F.; Van Steenbergen, W. Malignancies and mortality in 200 patients with primary sclerosering cholangitis: A long-term single-centre study. Liver Int. 2012, 32, 214-222. [CrossRef]

75. Karlsen, T.H.; Folseraas, T.; Thorburn, D.; Vesterhus, M. Primary sclerosing cholangitis—A comprehensive review. J. Hepatol. 2017, 67, 1298-1323. [CrossRef]

76. Carpentier, R.; Suner, R.E.; van Hul, N.; Kopp, J.L.; Beaudry, J.B.; Cordi, S.; Antoniou, A.; Raynaud, P.; Lepreux, S.; Jacquemin, P.; et al. Embryonic ductal plate cells give rise to cholangiocytes, periportal hepatocytes, and adult liver progenitor cells. Gastroenterology 2011, 141, 1432-1438.e4. [CrossRef] [PubMed]

77. Boyer, J.L. Bile formation and secretion. Compr. Physiol. 2013, 3, 1035-1078. [PubMed]

78. Guicciardi, M.E.; Trussoni, C.E.; LaRusso, N.F.; Gores, G.J. The spectrum of reactive cholangiocytes in primary sclerosing cholangitis. Hepatology 2020, 71, 741-748. [CrossRef] [PubMed]

79. Jensen, J.M.; Brix, F.; Kohr, P. General and specific aspects of experimental dose measurement in total body irradiation (tbi). Strahlenther. Onkol. 1986, 162, 250-253.

80. Poncy, A.; Antoniou, A.; Cordi, S.; Pierreux, C.E.; Jacquemin, P.; Lemaigre, F.P. Transcription factors sox4 and sox9 cooperatively control development of bile ducts. Dev. Biol. 2015, 404, 136-148. [CrossRef]

81. Mansini, A.P.; Peixoto, E.; Thelen, K.M.; Gaspari, C.; Jin, S.; Gradilone, S.A. The cholangiocyte primary cilium in health and disease. Biochim. Biophys. Acta Mol. Basis Dis. 2018, 1864, 1245-1253. [CrossRef]

82. Medzhitov, R. Origin and physiological roles of inflammation. Nature 2008, 454, 428-435. [CrossRef] [PubMed]

83. Dranoff, J.A.; Wells, R.G. Portal fibroblasts: Underappreciated mediators of biliary fibrosis. Hepatology 2010, 51, 1438-1444. [CrossRef]

84. Kisseleva, T.; Cong, M.; Paik, Y.; Scholten, D.; Jiang, C.; Benner, C.; Iwaisako, K.; Moore-Morris, T.; Scott, B.; Tsukamoto, H.; et al. Myofibroblasts revert to an inactive phenotype during regression of liver fibrosis. Proc. Natl. Acad. Sci. USA 2012, 109, 9448-9453. [CrossRef] [PubMed]

85. Iwaisako, K.; Jiang, C.; Zhang, M.; Cong, M.; Moore-Morris, T.J.; Park, T.J.; Liu, X.; Xu, J.; Wang, P.; Paik, Y.H.; et al. Origin of myofibroblasts in the fibrotic liver in mice. Proc. Natl. Acad. Sci. USA 2014, 111, E3297-E3305. [CrossRef]

86. Chen, Y.; Gilbert, M.A.; Grochowski, C.M.; McEldrew, D.; Llewellyn, J.; Waisbourd-Zinman, O.; Hakonarson, H.; Bailey-Wilson, J.E.; Russo, P.; Wells, R.G.; et al. A genome-wide association study identifies a susceptibility locus for biliary atresia on 2p16.1 within the gene efemp1. PLoS Genet. 2018, 14, e1007532. [CrossRef] [PubMed]

87. Fausther, M.; Dranoff, J.A. Beyond scar formation: Portal myofibroblast-mediated angiogenesis in the fibrotic liver. Hepatology 2015, 61, 766-768. [CrossRef]

88. Koyama, Y.; Wang, P.; Liang, S.; Iwaisako, K.; Liu, X.; Xu, J.; Zhang, M.; Sun, M.; Cong, M.; Karin, D.; et al. Mesothelin/mucin 16 signaling in activated portal fibroblasts regulates cholestatic liver fibrosis. J. Clin. Investig. 2017, 127, 1254-1270. [CrossRef]

89. Nishio, T.; Hu, R.; Koyama, Y.; Liang, S.; Rosenthal, S.B.; Yamamoto, G.; Karin, D.; Baglieri, J.; Ma, H.Y.; Xu, J.; et al. Activated hepatic stellate cells and portal fibroblasts contribute to cholestatic liver fibrosis in mdr2 knockout mice. J. Hepatol. 2019, 71, 573-585. [CrossRef] [PubMed]

90. Wells, R.G. The portal fibroblast: Not just a poor man's stellate cell. Gastroenterology 2014, 147, 41-47. [CrossRef]

91. Xu, J.; Liu, X.; Koyama, Y.; Wang, P.; Lan, T.; Kim, I.G.; Kim, I.H.; Ma, H.Y.; Kisseleva, T. The types of hepatic myofibroblasts contributing to liver fibrosis of different etiologies. Front. Pharmacol. 2014, 5, 167. [CrossRef]

92. Libbrecht, L.; Cassiman, D.; Desmet, V.; Roskams, T. The correlation between portal myofibroblasts and development of intrahepatic bile ducts and arterial branches in human liver. Liver 2002, 22, 252-258. [CrossRef] [PubMed]

93. Braet, F.; Taatjes, D.J.; Wisse, E. Probing the unseen structure and function of liver cells through atomic force microscopy. Semin. Cell Dev. Biol. 2018, 73, 13-30. [CrossRef] [PubMed]

94. Wisse, E. Ultrastructure and function of kupffer cells and other sinusoidal cells in the liver. Med. Chir. Digest. 1977, 6, 409-418.

95. Klaas, M.; Kangur, T.; Viil, J.; Maemets-Allas, K.; Minajeva, A.; Vadi, K.; Antsov, M.; Lapidus, N.; Jarvekulg, M.; Jaks, V. The alterations in the extracellular matrix composition guide the repair of damaged liver tissue. Sci. Rep. 2016, 6, 27398. [CrossRef]

96. Mallat, A.; Lotersztajn, S. Cellular mechanisms of tissue fibrosis. 5. Novel insights into liver fibrosis. Am. J. Physiol. Cell Physiol. 2013, 305, C789-C799. [CrossRef] 
97. Tsuchida, T.; Friedman, S.L. Mechanisms of hepatic stellate cell activation. Nat. Rev. Gastroenterol. Hepatol. 2017, 14, 397-411. [CrossRef] [PubMed]

98. Teratani, T.; Tomita, K.; Suzuki, T.; Oshikawa, T.; Yokoyama, H.; Shimamura, K.; Tominaga, S.; Hiroi, S.; Irie, R.; Okada, Y.; et al. A high-cholesterol diet exacerbates liver fibrosis in mice via accumulation of free cholesterol in hepatic stellate cells. Gastroenterology 2012, 142, 152-164.e10. [CrossRef] [PubMed]

99. Tsuchida, T.; Lee, Y.A.; Fujiwara, N.; Ybanez, M.; Allen, B.; Martins, S.; Fiel, M.I.; Goossens, N.; Chou, H.I.; Hoshida, Y.; et al. A simple diet- and chemical-induced murine nash model with rapid progression of steatohepatitis, fibrosis and liver cancer. $J$. Hepatol. 2018, 69, 385-395. [CrossRef]

100. Furuhashi, H.; Tomita, K.; Teratani, T.; Shimizu, M.; Nishikawa, M.; Higashiyama, M.; Takajo, T.; Shirakabe, K.; Maruta, K.; Okada, Y.; et al. Vitamin a-coupled liposome system targeting free cholesterol accumulation in hepatic stellate cells offers a beneficial therapeutic strategy for liver fibrosis. Hepatol. Res. 2018, 48, 397-407. [CrossRef]

101. Villeneuve, J.; Pelluard-Nehme, F.; Combe, C.; Carles, D.; Chaponnier, C.; Ripoche, J.; Balabaud, C.; Bioulac-Sage, P.; Lepreux, S. Immunohistochemical study of the phenotypic change of the mesenchymal cells during portal tract maturation in normal and fibrous (ductal plate malformation) fetal liver. Comp. Hepatol. 2009, 8, 5. [CrossRef] [PubMed]

102. Suzuki, K.; Tanaka, M.; Watanabe, N.; Saito, S.; Nonaka, H.; Miyajima, A. P75 neurotrophin receptor is a marker for precursors of stellate cells and portal fibroblasts in mouse fetal liver. Gastroenterology 2008, 135, 270-281.e3. [CrossRef] [PubMed]

103. Asahina, K.; Tsai, S.Y.; Li, P.; Ishii, M.; Maxson, R.E., Jr.; Sucov, H.M.; Tsukamoto, H. Mesenchymal origin of hepatic stellate cells, submesothelial cells, and perivascular mesenchymal cells during mouse liver development. Hepatology 2009, 49, 998-1011. [CrossRef] [PubMed]

104. Sawitza, I.; Kordes, C.; Reister, S.; Haussinger, D. The niche of stellate cells within rat liver. Hepatology 2009, 50, 1617-1624. [CrossRef] [PubMed]

105. Zhang, Q.D.; Xu, M.Y.; Cai, X.B.; Qu, Y.; Li, Z.H.; Lu, L.G. Myofibroblastic transformation of rat hepatic stellate cells: The role of notch signaling and epithelial-mesenchymal transition regulation. Eur. Rev. Med. Pharmacol. Sci. 2015, 19, 4130-4138. [PubMed]

106. Spee, B.; Carpino, G.; Schotanus, B.A.; Katoonizadeh, A.; Vander Borght, S.; Gaudio, E.; Roskams, T. Characterisation of the liver progenitor cell niche in liver diseases: Potential involvement of wnt and notch signalling. Gut 2010, 59, 247-257. [CrossRef]

107. Tanriverdi, G.; Kaya-Dagistanli, F.; Ayla, S.; Demirci, S.; Eser, M.; Unal, Z.S.; Cengiz, M.; Oktar, H. Resveratrol can prevent ccl(4)-induced liver injury by inhibiting notch signaling pathway. Histol. Histopathol. 2016, 31, 769-784. [PubMed]

108. Chen, Y.; Zheng, S.; Qi, D.; Zheng, S.; Guo, J.; Zhang, S.; Weng, Z. Inhibition of notch signaling by a gamma-secretase inhibitor attenuates hepatic fibrosis in rats. PLOS ONE 2012, 7, e46512.

109. Adams, J.M.; Jafar-Nejad, H. The roles of notch signaling in liver development and disease. Biomolecules 2019, 9, 608. [CrossRef]

110. Zhang, K.; Han, X.; Zhang, Z.; Zheng, L.; Hu, Z.; Yao, Q.; Cui, H.; Shu, G.; Si, M.; Li, C.; et al. The liver-enriched lnc-lfar1 promotes liver fibrosis by activating tgfbeta and notch pathways. Nat. Commun. 2017, 8, 144. [CrossRef]

111. Aimaiti, Y.; Jin, X.; Wang, W.; Chen, Z.; Li, D. Tgf-beta1 signaling regulates mouse hepatic stellate cell differentiation via the jagged1/notch pathway. Life Sci. 2018, 192, 221-230. [CrossRef]

112. Wallace, K.; Burt, A.D.; Wright, M.C. Liver fibrosis. Biochem. J. 2008, 411, 1-18. [CrossRef]

113. Wynn, T.A.; Vannella, K.M. Macrophages in tissue repair, regeneration, and fibrosis. Immunity 2016, 44, 450-462. [CrossRef] [PubMed]

114. Dropmann, A.; Dooley, S.; Dewidar, B.; Hammad, S.; Dediulia, T.; Werle, J.; Hartwig, V.; Ghafoory, S.; Woelfl, S.; Korhonen, H.; et al. Tgf-beta2 silencing to target biliary-derived liver diseases. Gut 2020, 69, 1677-1690. [CrossRef]

115. Athwal, V.S.; Pritchett, J.; Llewellyn, J.; Martin, K.; Camacho, E.; Raza, S.M.; Phythian-Adams, A.; Birchall, L.J.; Mullan, A.F.; $\mathrm{Su}, \mathrm{K}$; , et al. Sox 9 predicts progression toward cirrhosis in patients while its loss protects against liver fibrosis. EMBO Mol. Med. 2017, 9, 1696-1710. [CrossRef]

116. Duan, J.L.; Ruan, B.; Yan, X.C.; Liang, L.; Song, P.; Yang, Z.Y.; Liu, Y.; Dou, K.F.; Han, H.; Wang, L. Endothelial notch activation reshapes the angiocrine of sinusoidal endothelia to aggravate liver fibrosis and blunt regeneration in mice. Hepatology 2018, 68, 677-690. [CrossRef] [PubMed]

117. Zhu, C.; Kim, K.; Wang, X.; Bartolome, A.; Salomao, M.; Dongiovanni, P.; Meroni, M.; Graham, M.J.; Yates, K.P.; Diehl, A.M.; et al. Hepatocyte notch activation induces liver fibrosis in nonalcoholic steatohepatitis. Sci. Transl. Med. 2018, 10, eaat0344. [CrossRef]

118. Fabris, L.; Spirli, C.; Cadamuro, M.; Fiorotto, R.; Strazzabosco, M. Emerging concepts in biliary repair and fibrosis. Am. J. Physiol. Gastrointest. Liver Physiol. 2017, 313, G102-G116. [CrossRef]

119. Planas-Paz, L.; Sun, T.; Pikiolek, M.; Cochran, N.R.; Bergling, S.; Orsini, V.; Yang, Z.; Sigoillot, F.; Jetzer, J.; Syed, M.; et al. Yap, but not rspo-lgr4/5, signaling in biliary epithelial cells promotes a ductular reaction in response to liver injury. Cell Stem Cell 2019, 25, 39-53.e10. [CrossRef] [PubMed]

120. Furth, N.; Aylon, Y.; Oren, M. P53 shades of hippo. Cell Death Differ. 2018, 25, 81-92. [CrossRef] [PubMed]

121. Bird, T.G.; Lu, W.Y.; Boulter, L.; Gordon-Keylock, S.; Ridgway, R.A.; Williams, M.J.; Taube, J.; Thomas, J.A.; Wojtacha, D.; Gambardella, A.; et al. Bone marrow injection stimulates hepatic ductular reactions in the absence of injury via macrophagemediated tweak signaling. Proc. Natl. Acad. Sci. USA 2013, 110, 6542-6547. [CrossRef]

122. Jakubowski, A.; Ambrose, C.; Parr, M.; Lincecum, J.M.; Wang, M.Z.; Zheng, T.S.; Browning, B.; Michaelson, J.S.; Baetscher, M.; Wang, B.; et al. Tweak induces liver progenitor cell proliferation. J. Clin. Investig. 2005, 115, 2330-2340. [CrossRef] [PubMed]

123. Machado, M.V.; Diehl, A.M. Hedgehog signalling in liver pathophysiology. J. Hepatol. 2018, 68, 550-562. [CrossRef] 
124. Strazzabosco, M.; Fabris, L. Notch signaling in hepatocellular carcinoma: Guilty in association! Gastroenterology 2012, 143, 1430-1434. [CrossRef]

125. Omenetti, A.; Porrello, A.; Jung, Y.; Yang, L.; Popov, Y.; Choi, S.S.; Witek, R.P.; Alpini, G.; Venter, J.; Vandongen, H.M.; et al. Hedgehog signaling regulates epithelial-mesenchymal transition during biliary fibrosis in rodents and humans. J. Clin. Investig. 2008, 118, 3331-3342. [CrossRef]

126. Xie, G.; Karaca, G.; Swiderska-Syn, M.; Michelotti, G.A.; Kruger, L.; Chen, Y.; Premont, R.T.; Choi, S.S.; Diehl, A.M. Cross-talk between notch and hedgehog regulates hepatic stellate cell fate in mice. Hepatology 2013, 58, 1801-1813. [CrossRef]

127. Stasiulewicz, M.; Gray, S.D.; Mastromina, I.; Silva, J.C.; Bjorklund, M.; Seymour, P.A.; Booth, D.; Thompson, C.; Green, R.J.; Hall, E.A.; et al. A conserved role for notch signaling in priming the cellular response to shh through ciliary localisation of the key shh transducer smo. Development 2015, 142, 2291-2303. [CrossRef] [PubMed]

128. He, F.; Guo, F.C.; Li, Z.; Yu, H.C.; Ma, P.F.; Zhao, J.L.; Feng, L.; Li, W.N.; Liu, X.W.; Qin, H.Y.; et al. Myeloid-specific disruption of recombination signal binding protein jkappa ameliorates hepatic fibrosis by attenuating inflammation through cylindromatosis in mice. Hepatology 2015, 61, 303-314. [CrossRef]

129. Herrera, J.; Henke, C.A.; Bitterman, P.B. Extracellular matrix as a driver of progressive fibrosis. J. Clin. Investig. 2018, 128, 45-53. [CrossRef] [PubMed]

130. Monga, S.P. Beta-catenin signaling and roles in liver homeostasis, injury, and tumorigenesis. Gastroenterology 2015, 148, 1294-1310. [CrossRef]

131. Ramirez, T.; Li, Y.M.; Yin, S.; Xu, M.J.; Feng, D.; Zhou, Z.; Zang, M.; Mukhopadhyay, P.; Varga, Z.V.; Pacher, P.; et al. Aging aggravates alcoholic liver injury and fibrosis in mice by downregulating sirtuin 1 expression. J. Hepatol. 2017, 66, 601-609. [CrossRef] [PubMed]

132. Roeb, E. Matrix metalloproteinases and liver fibrosis (translational aspects). Matrix Biol. 2018, 68-69, 463-473. [CrossRef]

133. Beljaars, L.; Daliri, S.; Dijkhuizen, C.; Poelstra, K.; Gosens, R. Wnt-5a regulates tgf-beta-related activities in liver fibrosis. Am. J. Physiol. Gastrointest. Liver Physiol. 2017, 312, G219-G227. [CrossRef]

134. Carpino, G.; Nobili, V.; Renzi, A.; De Stefanis, C.; Stronati, L.; Franchitto, A.; Alisi, A.; Onori, P.; De Vito, R.; Alpini, G.; et al. Macrophage activation in pediatric nonalcoholic fatty liver disease (nafld) correlates with hepatic progenitor cell response via wnt3a pathway. PLoS ONE 2016, 11, e0157246. [CrossRef] [PubMed]

135. Ma, Z.G.; Lv, X.D.; Zhan, L.L.; Chen, L.; Zou, Q.Y.; Xiang, J.Q.; Qin, J.L.; Zhang, W.W.; Zeng, Z.J.; Jin, H.; et al. Human urokinase-type plasminogen activator gene-modified bone marrow-derived mesenchymal stem cells attenuate liver fibrosis in rats by down-regulating the wnt signaling pathway. World J. Gastroenterol. 2016, 22, 2092-2103. [CrossRef]

136. Xiong, W.J.; Hu, L.J.; Jian, Y.C.; Wang, L.J.; Jiang, M.; Li, W.; He, Y. Wnt5a participates in hepatic stellate cell activation observed by gene expression profile and functional assays. World J. Gastroenterol. 2012, 18, 1745-1752. [CrossRef]

137. Cheng, J.H.; She, H.; Han, Y.P.; Wang, J.; Xiong, S.; Asahina, K.; Tsukamoto, H. Wnt antagonism inhibits hepatic stellate cell activation and liver fibrosis. Am. J. Physiol. Gastrointest. Liver Physiol. 2008, 294, G39-G49. [CrossRef] [PubMed]

138. Lai, K.K.Y.; Kweon, S.M.; Chi, F.; Hwang, E.; Kabe, Y.; Higashiyama, R.; Qin, L.; Yan, R.; Wu, R.P.; Lai, K.; et al. Stearoyl-coa desaturase promotes liver fibrosis and tumor development in mice via a wnt positive-signaling loop by stabilization of low-density lipoprotein-receptor-related proteins 5 and 6. Gastroenterology 2017, 152, 1477-1491. [CrossRef]

139. Wang, J.N.; Li, L.; Li, L.Y.; Yan, Q.; Li, J.; Xu, T. Emerging role and therapeutic implication of wnt signaling pathways in liver fibrosis. Gene 2018, 674, 57-69. [CrossRef]

140. Pradhan-Sundd, T.; Kosar, K.; Saggi, H.; Zhang, R.; Vats, R.; Cornuet, P.; Green, S.; Singh, S.; Zeng, G.; Sundd, P.; et al. Wnt/betacatenin signaling plays a protective role in the mdr2 knockout murine model of cholestatic liver disease. Hepatology 2020, 71, 1732-1749. [CrossRef]

141. Minden, A.; Karin, M. Regulation and function of the jnk subgroup of map kinases. Biochim Biophys Acta 1997, 1333, F85-F104. [CrossRef]

142. Weston, C.R.; Davis, R.J. The jnk signal transduction pathway. Curr. Opin. Cell Biol. 2007, 19, 142-149. [CrossRef] [PubMed]

143. Zhao, G.; Hatting, M.; Nevzorova, Y.A.; Peng, J.; Hu, W.; Boekschoten, M.V.; Roskams, T.; Muller, M.; Gassler, N.; Liedtke, C.; et al. Jnk1 in murine hepatic stellate cells is a crucial mediator of liver fibrogenesis. Gut 2014, 63, 1159-1172. [CrossRef] [PubMed]

144. Kluwe, J.; Pradere, J.P.; Gwak, G.Y.; Mencin, A.; De Minicis, S.; Osterreicher, C.H.; Colmenero, J.; Bataller, R.; Schwabe, R.F. Modulation of hepatic fibrosis by c-jun-n-terminal kinase inhibition. Gastroenterology 2010, 138, 347-359. [CrossRef] [PubMed]

145. Papa, S.; Bubici, C.; Zazzeroni, F.; Franzoso, G. Mechanisms of liver disease: Cross-talk between the nf-kappab and jnk pathways. Biol. Chem. 2009, 390, 965-976. [CrossRef] [PubMed]

146. Alper, S.L. Molecular physiology and genetics of na+-independent slc4 anion exchangers. J. Exp. Biol. 2009, 212, 1672-1683. [CrossRef]

147. Trampert, D.C.; van de Graaf, S.F.J.; Jongejan, A.; Oude Elferink, R.P.J.; Beuers, U. Hepatobiliary acid-base homeostasis: Insights from analogous secretory epithelia. J. Hepatol. 2021, 74, 428-441. [CrossRef]

148. Prieto, J.; Qian, C.; Garcia, N.; Diez, J.; Medina, J.F. Abnormal expression of anion exchanger genes in primary biliary cirrhosis. Gastroenterology 1993, 105, 572-578. [CrossRef]

149. Medina, J.F.; Martinez, A.; Vazquez, J.J.; Prieto, J. Decreased anion exchanger 2 immunoreactivity in the liver of patients with primary biliary cirrhosis. Hepatology 1997, 25, 12-17. [CrossRef] [PubMed] 
150. Melero, S.; Spirli, C.; Zsembery, A.; Medina, J.F.; Joplin, R.E.; Duner, E.; Zuin, M.; Neuberger, J.M.; Prieto, J.; Strazzabosco, M. Defective regulation of cholangiocyte $\mathrm{cl}-/ \mathrm{hco3}(-)$ and na+/h+ exchanger activities in primary biliary cirrhosis. Hepatology 2002, 35, 1513-1521. [CrossRef] [PubMed]

151. Salas, J.T.; Banales, J.M.; Sarvide, S.; Recalde, S.; Ferrer, A.; Uriarte, I.; Oude Elferink, R.P.; Prieto, J.; Medina, J.F. Ae2a,b-deficient mice develop antimitochondrial antibodies and other features resembling primary biliary cirrhosis. Gastroenterology 2008, 134, 1482-1493. [CrossRef]

152. Castro, R.E.; Rodrigues, C.M.P. Cell death and micrornas in cholestatic liver diseases: Update on potential therapeutic applications. Curr. Drug Targets 2017, 18, 921-931. [CrossRef] [PubMed]

153. Erice, O.; Munoz-Garrido, P.; Vaquero, J.; Perugorria, M.J.; Fernandez-Barrena, M.G.; Saez, E.; Santos-Laso, A.; Arbelaiz, A.; Jimenez-Aguero, R.; Fernandez-Irigoyen, J.; et al. Microrna-506 promotes primary biliary cholangitis-like features in cholangiocytes and immune activation. Hepatology 2018, 67, 1420-1440. [CrossRef]

154. Dyson, J.K.; Hirschfield, G.M.; Adams, D.H.; Beuers, U.; Mann, D.A.; Lindor, K.D.; Jones, D.E. Novel therapeutic targets in primary biliary cirrhosis. Nat. Rev. Gastroenterol. Hepatol. 2015, 12, 147-158. [CrossRef] [PubMed]

155. Padgett, K.A.; Lan, R.Y.; Leung, P.C.; Lleo, A.; Dawson, K.; Pfeiff, J.; Mao, T.K.; Coppel, R.L.; Ansari, A.A.; Gershwin, M.E. Primary biliary cirrhosis is associated with altered hepatic microrna expression. J. Autoimmun. 2009, 32, 246-253. [CrossRef]

156. Minagawa, N.; Nagata, J.; Shibao, K.; Masyuk, A.I.; Gomes, D.A.; Rodrigues, M.A.; Lesage, G.; Akiba, Y.; Kaunitz, J.D.; Ehrlich, B.E.; et al. Cyclic amp regulates bicarbonate secretion in cholangiocytes through release of atp into bile. Gastroenterology 2007, 133, 1592-1602. [CrossRef] [PubMed]

157. Banales, J.M.; Saez, E.; Uriz, M.; Sarvide, S.; Urribarri, A.D.; Splinter, P.; Tietz Bogert, P.S.; Bujanda, L.; Prieto, J.; Medina, J.F.; et al. Up-regulation of microrna 506 leads to decreased cl-/hco3- anion exchanger 2 expression in biliary epithelium of patients with primary biliary cirrhosis. Hepatology 2012, 56, 687-697. [CrossRef]

158. Monte, M.J.; Marin, J.J.; Antelo, A.; Vazquez-Tato, J. Bile acids: Chemistry, physiology, and pathophysiology. World J. Gastroenterol. 2009, 15, 804-816. [CrossRef]

159. Song, K.H.; Li, T.; Owsley, E.; Chiang, J.Y. A putative role of micro rna in regulation of cholesterol 7alpha-hydroxylase expression in human hepatocytes. J. Lipid Res. 2010, 51, 2223-2233. [CrossRef] [PubMed]

160. Allen, R.M.; Marquart, T.J.; Albert, C.J.; Suchy, F.J.; Wang, D.Q.; Ananthanarayanan, M.; Ford, D.A.; Baldan, A. Mir-33 controls the expression of biliary transporters, and mediates statin- and diet-induced hepatotoxicity. EMBO Mol. Med. 2012, 4, 882-895. [CrossRef]

161. Li, T.; Francl, J.M.; Boehme, S.; Chiang, J.Y. Regulation of cholesterol and bile acid homeostasis by the cholesterol 7alphahydroxylase/steroid response element-binding protein 2/microrna-33a axis in mice. Hepatology 2013, 58, 1111-1121. [CrossRef]

162. Marin, J.J.; Bujanda, L.; Banales, J.M. Micrornas and cholestatic liver diseases. Curr. Opin. Gastroenterol. 2014, 30, 303-309. [CrossRef] [PubMed]

163. Gulamhusein, A.F.; Hirschfield, G.M. Pathophysiology of primary biliary cholangitis. Best Pract. Res. Clin. Gastroenterol. 2018, 34-35, 17-25. [CrossRef]

164. Yeaman, S.J.; Fussey, S.P.; Danner, D.J.; James, O.F.; Mutimer, D.J.; Bassendine, M.F. Primary biliary cirrhosis: Identification of two major $\mathrm{m} 2$ mitochondrial autoantigens. Lancet 1988, 1, 1067-1070. [CrossRef]

165. Kita, H.; Matsumura, S.; He, X.S.; Ansari, A.A.; Lian, Z.X.; Van de Water, J.; Coppel, R.L.; Kaplan, M.M.; Gershwin, M.E. Quantitative and functional analysis of pdc-e2-specific autoreactive cytotoxic t lymphocytes in primary biliary cirrhosis. J. Clin. Investig. 2002, 109, 1231-1240. [CrossRef] [PubMed]

166. Kita, H.; Lian, Z.X.; Van de Water, J.; He, X.S.; Matsumura, S.; Kaplan, M.; Luketic, V.; Coppel, R.L.; Ansari, A.A.; Gershwin, M.E. Identification of hla-a2-restricted $\mathrm{cd} 8(+)$ cytotoxic $t$ cell responses in primary biliary cirrhosis: $\mathrm{T}$ cell activation is augmented by immune complexes cross-presented by dendritic cells. J. Exp. Med. 2002, 195, 113-123. [CrossRef] [PubMed]

167. Lleo, A.; Bowlus, C.L.; Yang, G.X.; Invernizzi, P.; Podda, M.; Van de Water, J.; Ansari, A.A.; Coppel, R.L.; Worman, H.J.; Gores, G.J.; et al. Biliary apotopes and anti-mitochondrial antibodies activate innate immune responses in primary biliary cirrhosis. Hepatology 2010, 52, 987-998. [CrossRef]

168. Tanaka, A.; Leung, P.S.C.; Gershwin, M.E. The genetics of primary biliary cholangitis. Curr. Opin. Gastroenterol. 2019, 35, 93-98. [CrossRef]

169. Ellinghaus, D.; Jostins, L.; Spain, S.L.; Cortes, A.; Bethune, J.; Han, B.; Park, Y.R.; Raychaudhuri, S.; Pouget, J.G.; Hubenthal, M.; et al. Analysis of five chronic inflammatory diseases identifies 27 new associations and highlights disease-specific patterns at shared loci. Nat. Genet. 2016, 48, 510-518. [CrossRef] [PubMed]

170. Goyette, P.; Boucher, G.; Mallon, D.; Ellinghaus, E.; Jostins, L.; Huang, H.; Ripke, S.; Gusareva, E.S.; Annese, V.; Hauser, S.L.; et al. High-density mapping of the mhc identifies a shared role for hla-drb1*01:03 in inflammatory bowel diseases and heterozygous advantage in ulcerative colitis. Nat. Genet. 2015, 47, 172-179. [CrossRef]

171. Karlsen, T.H.; Franke, A.; Melum, E.; Kaser, A.; Hov, J.R.; Balschun, T.; Lie, B.A.; Bergquist, A.; Schramm, C.; Weismuller, T.J.; et al. Genome-wide association analysis in primary sclerosing cholangitis. Gastroenterology 2010, 138, 1102-1111. [CrossRef] [PubMed]

172. Folseraas, T.; Melum, E.; Rausch, P.; Juran, B.D.; Ellinghaus, E.; Shiryaev, A.; Laerdahl, J.K.; Ellinghaus, D.; Schramm, C.; Weismuller, T.J.; et al. Extended analysis of a genome-wide association study in primary sclerosing cholangitis detects multiple novel risk loci. J. Hepatol. 2012, 57, 366-375. [CrossRef] [PubMed] 
173. Beuers, U.; Hohenester, S.; de Buy Wenniger, L.J.; Kremer, A.E.; Jansen, P.L.; Elferink, R.P. The biliary hco(3)(-) umbrella: A unifying hypothesis on pathogenetic and therapeutic aspects of fibrosing cholangiopathies. Hepatology 2010, 52, 1489-1496. [CrossRef] [PubMed]

174. Cai, S.Y.; Boyer, J.L. The role of inflammation in the mechanisms of bile acid-induced liver damage. Dig. Dis. 2017, 35, 232-234. [CrossRef]

175. Penz-Osterreicher, M.; Osterreicher, C.H.; Trauner, M. Fibrosis in autoimmune and cholestatic liver disease. Best Pract. Res. Clin. Gastroenterol. 2011, 25, 245-258. [CrossRef]

176. Trauner, M.; Fickert, P.; Halilbasic, E.; Moustafa, T. Lessons from the toxic bile concept for the pathogenesis and treatment of cholestatic liver diseases. Wien. Med. Wochenschr. 2008, 158, 542-548. [CrossRef] [PubMed]

177. Fickert, P.; Fuchsbichler, A.; Wagner, M.; Zollner, G.; Kaser, A.; Tilg, H.; Krause, R.; Lammert, F.; Langner, C.; Zatloukal, K.; et al. Regurgitation of bile acids from leaky bile ducts causes sclerosing cholangitis in mdr2 (abcb4) knockout mice. Gastroenterology 2004, 127, 261-274. [CrossRef]

178. Michalopoulos, G.K.; Barua, L.; Bowen, W.C. Transdifferentiation of rat hepatocytes into biliary cells after bile duct ligation and toxic biliary injury. Hepatology 2005, 41, 535-544. [CrossRef]

179. Ezure, T.; Sakamoto, T.; Tsuji, H.; Lunz, J.G., 3rd; Murase, N.; Fung, J.J.; Demetris, A.J. The development and compensation of biliary cirrhosis in interleukin-6-deficient mice. Am. J. Pathol. 2000, 156, 1627-1639. [CrossRef]

180. Lunz, J.G., 3rd; Contrucci, S.; Ruppert, K.; Murase, N.; Fung, J.J.; Starzl, T.E.; Demetris, A.J. Replicative senescence of biliary epithelial cells precedes bile duct loss in chronic liver allograft rejection: Increased expression of p21(waf1/cip1) as a disease marker and the influence of immunosuppressive drugs. Am. J. Pathol. 2001, 158, 1379-1390. [CrossRef]

181. Matsumoto, K.; Fujii, H.; Michalopoulos, G.; Fung, J.J.; Demetris, A.J. Human biliary epithelial cells secrete and respond to cytokines and hepatocyte growth factors in vitro: Interleukin-6, hepatocyte growth factor and epidermal growth factor promote DNA synthesis in vitro. Hepatology 1994, 20, 376-382. [CrossRef] [PubMed]

182. Mariotti, V.; Cadamuro, M.; Spirli, C.; Fiorotto, R.; Strazzabosco, M.; Fabris, L. Animal models of cholestasis: An update on inflammatory cholangiopathies. Biochim. Biophys. Acta Mol. Basis Dis. 2019, 1865, 954-964. [CrossRef] [PubMed]

183. Gorelik, L.; Flavell, R.A. Abrogation of tgfbeta signaling in $t$ cells leads to spontaneous $t$ cell differentiation and autoimmune disease. Immunity 2000, 12, 171-181. [CrossRef]

184. Ishigame, H.; Mosaheb, M.M.; Sanjabi, S.; Flavell, R.A. Truncated form of tgf-betarii, but not its absence, induces memory cd8+ $t$ cell expansion and lymphoproliferative disorder in mice. J. Immunol. 2013, 190, 6340-6350. [CrossRef]

185. Vergani, D.; Alvarez, F.; Bianchi, F.B.; Cancado, E.L.; Mackay, I.R.; Manns, M.P.; Nishioka, M.; Penner, E.; International Autoimmune Hepatitis, G. Liver autoimmune serology: A consensus statement from the committee for autoimmune serology of the international autoimmune hepatitis group. J. Hepatol. 2004, 41, 677-683. [CrossRef] [PubMed]

186. Harada, K.; Sudo, Y.; Kono, N.; Ozaki, S.; Tsuneyama, K.; Gershwin, M.E.; Nakanuma, Y. In situ nucleic acid detection of pdc-e2, bcoadc-e2, ogdc-e2, pdc-e1alpha, bcoadc-e1alpha, ogdc-e1, and the e3 binding protein (protein $\mathrm{x}$ ) in primary biliary cirrhosis. Hepatology 1999, 30, 36-45. [CrossRef] [PubMed]

187. Bauer, A.; Habior, A. Detection of autoantibodies against nucleoporin p62 in sera of patients with primary biliary cholangitis. Ann. Lab. Med. 2019, 39, 291-298. [CrossRef] [PubMed]

188. Bauer, A.; Habior, A.; Wieszczy, P.; Gawel, D. Analysis of autoantibodies against promyelocytic leukemia nuclear body components and biochemical parameters in sera of patients with primary biliary cholangitis. Diagnostics 2021, 11, 587. [CrossRef]

189. Liu, Z.Y.; Xu, L.; Liu, B. Detection of anti-kelch-like 12 and anti-hexokinase 1 antibodies in primary biliary cholangitis patients in china. Rev. Esp. Enferm. Dig. 2020. [CrossRef]

190. Hausdorf, G.; Roggenbuck, D.; Feist, E.; Buttner, T.; Jungblut, P.R.; Conrad, K.; Berg, C.; Klein, R. Autoantibodies to asialoglycoprotein receptor (asgpr) measured by a novel elisa-revival of a disease-activity marker in autoimmune hepatitis. Clin. Chim. Acta 2009, 408, 19-24. [CrossRef]

191. Reig, A.; Norman, G.L.; Garcia, M.; Shums, Z.; Ruiz-Gaspa, S.; Bentow, C.; Mahler, M.; Romera, M.A.; Vinas, O.; Pares, A. Novel anti-hexokinase 1 antibodies are associated with poor prognosis in patients with primary biliary cholangitis. Am. J. Gastroenterol. 2020, 115, 1634-1641. [CrossRef] [PubMed]

192. Terjung, B.; Spengler, U.; Sauerbruch, T.; Worman, H.J. "Atypical p-anca" in ibd and hepatobiliary disorders react with a 50-kilodalton nuclear envelope protein of neutrophils and myeloid cell lines. Gastroenterology 2000, 119, 310-322. [CrossRef] [PubMed]

193. Jendrek, S.T.; Gotthardt, D.; Nitzsche, T.; Widmann, L.; Korf, T.; Michaels, M.A.; Weiss, K.H.; Liaskou, E.; Vesterhus, M.; Karlsen, T.H.; et al. Anti-gp2 iga autoantibodies are associated with poor survival and cholangiocarcinoma in primary sclerosing cholangitis. Gut 2017, 66, 137-144. [CrossRef]

194. Beuers, U.; Trauner, M.; Jansen, P.; Poupon, R. New paradigms in the treatment of hepatic cholestasis: From udca to fxr, pxr and beyond. J. Hepatol. 2015, 62, S25-S37. [CrossRef] [PubMed]

195. Lindor, K.D.; Kowdley, K.V.; Luketic, V.A.; Harrison, M.E.; McCashland, T.; Befeler, A.S.; Harnois, D.; Jorgensen, R.; Petz, J.; Keach, J.; et al. High-dose ursodeoxycholic acid for the treatment of primary sclerosing cholangitis. Hepatology 2009, 50, 808-814. [CrossRef]

196. Poupon, R.E.; Poupon, R.; Balkau, B. Ursodiol for the long-term treatment of primary biliary cirrhosis. The udca-pbc study group. N. Engl. J. Med. 1994, 330, 1342-1347. [CrossRef] 
197. Fiorucci, S.; Rizzo, G.; Antonelli, E.; Renga, B.; Mencarelli, A.; Riccardi, L.; Orlandi, S.; Pruzanski, M.; Morelli, A.; Pellicciari, R. A farnesoid $x$ receptor-small heterodimer partner regulatory cascade modulates tissue metalloproteinase inhibitor-1 and matrix metalloprotease expression in hepatic stellate cells and promotes resolution of liver fibrosis. J. Pharmacol. Exp. Ther. 2005, 314, 584-595. [CrossRef]

198. Hirschfield, G.M.; Mason, A.; Luketic, V.; Lindor, K.; Gordon, S.C.; Mayo, M.; Kowdley, K.V.; Vincent, C.; Bodhenheimer, H.C., Jr.; Pares, A.; et al. Efficacy of obeticholic acid in patients with primary biliary cirrhosis and inadequate response to ursodeoxycholic acid. Gastroenterology 2015, 148, 751-761.e8. [CrossRef]

199. Levy, C.; Peter, J.A.; Nelson, D.R.; Keach, J.; Petz, J.; Cabrera, R.; Clark, V.; Firpi, R.J.; Morelli, G.; Soldevila-Pico, C.; et al. Pilot study: Fenofibrate for patients with primary biliary cirrhosis and an incomplete response to ursodeoxycholic acid. Aliment. Pharmacol. Ther. 2011, 33, 235-242. [CrossRef]

200. Ghonem, N.S.; Auclair, A.M.; Hemme, C.L.; Gallucci, G.M.; de la Rosa Rodriguez, R.; Boyer, J.L.; Assis, D.N. Fenofibrate improves liver function and reduces the toxicity of the bile acid pool in patients with primary biliary cholangitis and primary sclerosing cholangitis who are partial responders to ursodiol. Clin. Pharmacol. Ther. 2020, 108, 1213-1223. [CrossRef]

201. Corpechot, C.; Chazouilleres, O.; Lemoinne, S.; Rousseau, A. Letter: Reduction in projected mortality or need for liver transplantation associated with bezafibrate add-on in primary biliary cholangitis with incomplete udca response. Aliment. Pharmacol. Ther. 2019, 49, 236-238. [CrossRef]

202. de Vries, E.; Bolier, R.; Goet, J.; Pares, A.; Verbeek, J.; de Vree, M.; Drenth, J.; van Erpecum, K.; van Nieuwkerk, K.; van der Heide, F.; et al. Fibrates for itch (fitch) in fibrosing cholangiopathies: A double-blind, randomized, placebo-controlled trial. Gastroenterology 2020, 160, 734-743.e6. [CrossRef]

203. Lemoinne, S.; Corpechot, C.; Fankem, A.K.; Gaouar, F.; Poupon, R.; Chazouillères, O. Fibrates improve liver tests in primary sclerosing cholangitis with incomplete biochemical response to ursodeoxycholic acid: Update of a pilote study: 335 . Hepatology 2014, 60, 521-528.

204. Hirschfield, G.; Boudes, P.; Bowlus, C.; Gitlin, N.; Michael, G.; Harrison, S.; Gordon, S.; Aspinall, R.; Doerffel, Y.; Kremer, A. Treatment efficacy and safety of seladelpar, a selective peroxisome proliferator-activated receptor delta agonist, in primary biliary cholangitis patients: 12-and 26-week analysis from an ongoing international, randomized, dose raging phase 2 study. J. Hepatol. 2018, 68, S105-S106. [CrossRef]

205. Schattenberg, J.M.; Pares, A.; Kowdley, K.V.; Heneghan, M.A.; Caldwell, S.; Pratt, D.; Bonder, A.; Hirschfield, G.M.; Levy, C.; Vierling, J.; et al. A randomized placebo-controlled trial of elafibranor in patients with primary biliary cholangitis and incomplete response to udca. J. Hepatol. 2021. [CrossRef] [PubMed]

206. Lindor, K.D.; Gershwin, M.E.; Poupon, R.; Kaplan, M.; Bergasa, N.V.; Heathcote, E.J.; American Association for Study of Liver, D. Primary biliary cirrhosis. Hepatology 2009, 50, 291-308. [CrossRef] [PubMed]

207. Trauner, M.; Gulamhusein, A.; Hameed, B.; Caldwell, S.; Shiffman, M.L.; Landis, C.; Eksteen, B.; Agarwal, K.; Muir, A.; Rushbrook, S.; et al. The nonsteroidal farnesoid $x$ receptor agonist cilofexor (gs-9674) improves markers of cholestasis and liver injury in patients with primary sclerosing cholangitis. Hepatology 2019, 70, 788-801. [CrossRef]

208. Goldstein, J.; Levy, C. Novel and emerging therapies for cholestatic liver diseases. Liver Int. 2018, 38, 1520-1535. [CrossRef] [PubMed]

209. Wagner, M.; Fickert, P. Time for the dawn of multimodal therapies and the dusk for mono-therapeutic trials for cholestatic liver diseases? Liver Int. 2018, 38, 991-994. [CrossRef]

210. Khanna, A.; Jopson, L.; Howel, D.; Bryant, A.; Blamire, A.; Newton, J.L.; Jones, D.E. Rituximab is ineffective for treatment of fatigue in primary biliary cholangitis: A phase 2 randomized controlled trial. Hepatology 2019, 70, 1646-1657. [CrossRef]

211. Muir, A.J.; Levy, C.; Janssen, H.L.A.; Montano-Loza, A.J.; Shiffman, M.L.; Caldwell, S.; Luketic, V.; Ding, D.; Jia, C.; McColgan, B.J.; et al. Simtuzumab for primary sclerosing cholangitis: Phase 2 study results with insights on the natural history of the disease. Hepatology 2019, 69, 684-698. [CrossRef]

212. Ali, A.H.; Damman, J.; Shah, S.B.; Davies, Y.; Hurwitz, M.; Stephen, M.; Lemos, L.M.; Carey, E.J.; Lindor, K.D.; Buness, C.W.; et al. Open-label prospective therapeutic clinical trials: Oral vancomycin in children and adults with primary sclerosing cholangitis. Scand. J. Gastroenterol. 2020, 55, 941-950. [CrossRef]

213. Tabibian, J.H.; Weeding, E.; Jorgensen, R.A.; Petz, J.L.; Keach, J.C.; Talwalkar, J.A.; Lindor, K.D. Randomised clinical trial: Vancomycin or metronidazole in patients with primary sclerosing cholangitis-A pilot study. Aliment. Pharmacol. Ther. 2013, 37, 604-612. [CrossRef] [PubMed]

214. Tabibian, J.H.; Gossard, A.; El-Youssef, M.; Eaton, J.E.; Petz, J.; Jorgensen, R.; Enders, F.B.; Tabibian, A.; Lindor, K.D. Prospective clinical trial of rifaximin therapy for patients with primary sclerosing cholangitis. Am. J. Ther. 2017, 24, e56-e63. [CrossRef]

215. Assis, D.N.; Abdelghany, O.; Cai, S.Y.; Gossard, A.A.; Eaton, J.E.; Keach, J.C.; Deng, Y.; Setchell, K.D.; Ciarleglio, M.; Lindor, K.D.; et al. Combination therapy of all-trans retinoic acid with ursodeoxycholic acid in patients with primary sclerosing cholangitis: A human pilot study. J. Clin. Gastroenterol. 2017, 51, e11-e16. [CrossRef]

216. Gochanour, E.M.; Kowdley, K.V. Investigational drugs in early phase development for primary biliary cholangitis. Expert Opin. Investig. Drugs 2021, 30, 131-141. [CrossRef] [PubMed]

217. Hirschfield, G.M.; Chazouilleres, O.; Drenth, J.P.; Thorburn, D.; Harrison, S.A.; Landis, C.S.; Mayo, M.J.; Muir, A.J.; Trotter, J.F.; Leeming, D.J.; et al. Effect of ngm282, an fgf19 analogue, in primary sclerosing cholangitis: A multicenter, randomized, double-blind, place-bo-controlled phase ii trial. J. Hepatol. 2019, 70, 483-493. [CrossRef] [PubMed] 